\title{
Per Se Drugged Driving Laws and Traffic Fatalities
}

\author{
D. Mark Anderson \\ Department of Agricultural Economics and Economics \\ Montana State University \\ dwight.anderson@montana.edu \\ Daniel I. Rees \\ Department of Economics \\ University of Colorado Denver \\ daniel.rees@ucdenver.edu
}

January 2015

In an effort to reduce drugged driving by 10 percent, the Office of National Drug Control Policy is encouraging all states to adopt per se drugged driving laws, which make it illegal to operate a motor vehicle with a controlled substance in the system. To date, 20 states have passed per se drugged driving laws, yet little is known about their effectiveness. Using data from the Fatality Analysis Reporting System for the period 1990-2010, the current study examines the relationship between these laws and traffic fatalities, the leading cause of death among Americans ages 5 through 34 . Our results provide no evidence that per se drugged driving laws reduce traffic fatalities. 


\section{INTRODUCTION}

Arizona was the first state to pass a per se drugged driving law. As of June 28, 1990 it became illegal to operate a motor vehicle in Arizona with detectable levels of cocaine, marijuana, methamphetamine, phencyclidine (i.e., PCP) or any other controlled substance in the system. Arizona drivers who test positive for a controlled substance are presumed to be impaired and can be prosecuted without additional evidence.

Over the next two decades, 12 more states passed zero tolerance per se drugged driving laws, and 4 states passed laws specifying nonzero thresholds for controlled substances (or their metabolites) above which a driver is automatically considered impaired (Table 1). Nevada, Ohio, and Pennsylvania specify nonzero thresholds for marijuana and a variety of other controlled substances. Virginia specifies nonzero thresholds for cocaine, methamphetamine and phencyclidine, but does not specify thresholds for marijuana or tetrahydrocannabinol, the primary psychoactive agent in marijuana. ${ }^{1}$

Drugged driving is often characterized as a serious and growing threat to public safety (Leinwand 2004; Walsh and DuPont 2007; Westall 2010; Freeman and DyBuncio 2011; DuPont et al. 2012). Indeed, according to data from the 2010 National Survey on Drug Use and Health, 10.6 million Americans reported driving under the influence of an illicit drug in the past year; in comparison, 28.8 million Americans reported driving under the influence of alcohol (Substance Abuse and Mental Health Services Administration 2011). According to Compton and Berning

\footnotetext{
${ }^{1}$ More information on per se drugged driving laws is available from Lacey et al. (2010), Armentano (2013) and the National Alliance for Model State Drug Laws (2014). Since 2010, Montana, Oklahoma, and Washington have enacted per se drugged driving laws. In 2013, the Colorado legislature passed HB 1325, under which having 5 or more nanograms of THC per milliliter of blood gives rise to the "permissible inference" of driving while impaired (Ferner 2013a; Ingold 2013). Kentucky, Minnesota, and North Carolina are included among the 13 states that passed a zero-tolerance per se drugged driving law between 1990 and 2010, but the per se laws in these states exempt marijuana (Cordova 2007; National Alliance for Model State Drug Laws (2014).
} 
(2009), who analyzed data from the 2007 National Roadside Survey, more than 15 percent of drivers on weekend nights test positive for drugs.

In 2010, the Office of National Drug Control Policy (ONDCP) announced a goal of reducing drugged driving in the Unites States by 10 percent within five years (ONDCP 2010). In an effort to achieve this goal, the director of the ONDCP has repeatedly urged states to pass per se drugged driving laws (Kerlikowske 2012a; ONDCP 2012; Botticelli 2014). The Governors Highway Safety Association (GHSA) and Mothers Against Drunk Driving (MADD) have also expressed strong support for per se drugged driving laws. ${ }^{2}$ However, aside from anecdotal evidence that these laws make drugged driving easier to prosecute (Lacey et al. 2010, p. 5), next to nothing is known about their effectiveness (Walsh et al. 2004).

Using data from the Fatality Analysis Reporting System (FARS) for the period 19902010, the current study examines the relationship between per se drugged driving laws (hereafter referred to as "per se laws") and traffic fatalities. Estimates of this relationship are positive, but imprecise. Because of this imprecision, we cannot rule out the possibility that, as currently implemented, per se laws reduce traffic fatalities.

\footnotetext{
${ }^{2}$ On its website, the GHSA argues that reducing drug-impaired driving should be a "national priority" and encourages states to "adopt drug per se (zero tolerance) drug impairment laws." In 2011 Kerlikowske and the President of MADD, Jan Withers, announced a new partnership to raise public awareness regarding the consequences of drugged driving. Kerlikowske was quoted as saying:
}

Research shows that drugs have adverse effects on judgment, reaction time, and motor skills - all vital requirements for responsible driving...I can think of no greater organization with which to partner to save lives on our roadways than MADD. For decades, MADD has been a lynchpin in our Nation's efforts to make our roadways safer and I am proud to join them to help raise public awareness regarding the devastating consequences of drugged driving (ONDCP 2011a). 


\title{
2. BACKGROUND
}

\subsection{Substance use and driving}

Alcohol impairs driving-related functions such as concentration, hand-eye coordination, and reaction time (Kelly et al. 2004; Sewell et al. 2009). Not surprisingly, simulator, drivingcourse, and etiological studies, which are typically based on police crash and medical examiner reports, provide strong evidence that alcohol consumption leads to an increased risk of collision (Kelly et al. 2004; Sewell et al. 2009). Drivers under the influence of alcohol tend to underestimate the degree to which they are impaired (MacDonald et al. 2008; Marczinski et al. 2008; Robbe and O'Hanlon 1993; Sewell et al. 2009), drive faster, and take unnecessary risks (Burian et al. 2002; Ronen et al. 2008; Sewell et al. 2009).

Laboratory studies have shown that, like alcohol, tetrahydrocannabinol (THC) impairs driving-related functions (Kelly et al. 2004; Sewell et al. 2009). However, simulator and driving-course studies provide little evidence that marijuana use leads to an increased risk of collision (Kelly et al. 2004; Sewell et al. 2009) perhaps because drivers under the influence of marijuana tend to overestimate the degree to which they are impaired (Kelly et al. 2004; Sewell et al. 2009). ${ }^{3}$ Although a number of etiological studies have shown a positive association between marijuana use and the risk of collision, they have been described as "fraught with methodological problems" (Sewell et al. 2009, p. 189). More than 10 percent of U.S. drivers killed in traffic accidents test positive for cannabinols (Brady and Li 2013), but it is exceedingly

\footnotetext{
${ }^{3}$ According to Sewell et al. (2009, p. 186):
}

\begin{abstract}
Many investigators have suggested that the reason why marijuana does not result in an increased crash rate in laboratory tests despite demonstrable neurophysiologic impairments is that, unlike drivers under the influence of alcohol, who tend to underestimate their degree of impairment, marijuana users tend to overestimate their impairment, and consequently employ compensatory strategies.
\end{abstract}


difficult to account for the influence of other, difficult-to-observe factors potentially correlated with marijuana. Such factors could include, but are certainly not limited to, personality and an individual's attitude towards risk. ${ }^{4}$

If the relationship between marijuana use and the risk of collision is entirely spurious, per se laws could still be related to traffic fatalities through the use of other drugs. Nine percent of U.S. drivers killed in traffic accidents test positive for stimulants and 6 percent test positive for narcotics (Brady and Li 2013). Despite the fact that these drugs are used by a non-trivial fraction of drivers in the Unites States, very little is known about their impact on road safety (Kelly et al. 2004). Only a handful of etiological studies in this area have examined substances other than alcohol and marijuana, and even fewer simulator or driving course studies have been conducted. ${ }^{5}$ However, the consensus opinion among experts appears to be that, in high doses, most drugs are "likely to increase accident risk" (Kelly et al. 2004, p. 332).

\subsection{Per se laws and traffic fatalities}

Currently, all 50 states prohibit driving a motor vehicle with a blood alcohol concentration $(\mathrm{BAC})$ of 0.08 or greater. Drivers found to have a BAC greater than 0.08 are

\footnotetext{
${ }^{4}$ A recent meta-analysis concluded that acute cannabis consumption nearly doubled the risk "of being involved in a motor vehicle collision resulting in serious injury or death" (Asbridge et al. 2012, p. 4). However, the authors of this study noted that:
}

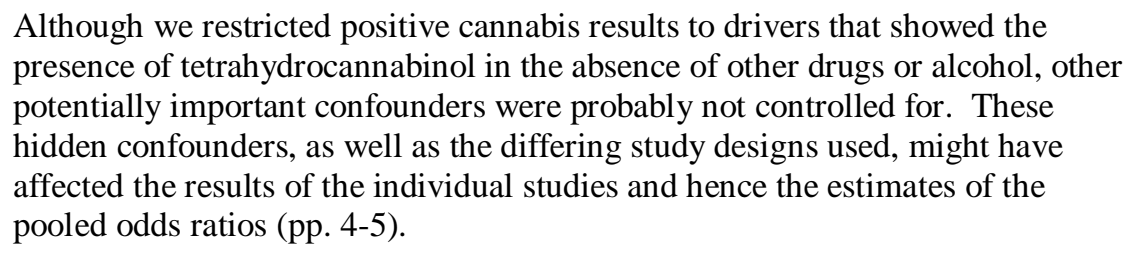
presence of tetrahydrocannabinol in the absence of other drugs or alcohol, other potentially important confounders were probably not controlled for. These hidden confounders, as well as the differing study designs used, might have affected the results of the individual studies and hence the estimates of the pooled odds ratios (pp. 4-5).

\footnotetext{
${ }^{5}$ Driving course and simulator studies have found evidence of benzodiazepine-induced impairment in driving performance (Kelly et al. 2004), but, to our knowledge, no simulator or driving course study has examined the impact of opioids or stimulants.
} 
presumed to be impaired and can be prosecuted without having to introduce additional evidence.

In contrast, most states do not set specific thresholds for controlled substances. As a

consequence, in order to prove impairment, the prosecution must rely on the results of a field

sobriety test or evidence that the motorist was driving erratically.

Per se laws are intended to make the job of prosecuting drugged drivers easier.

Supporters claim these laws deter drugged driving and, as a consequence, improve roadway safety (DuPont 2004; Walsh and DuPont 2007; Dupont et al. 2012; Wood 2013). ${ }^{6}$ However, because urine or blood samples must be obtained in order to determine the presence of a controlled substance in the system, and because probable cause is typically required in order to obtain toxicological evidence, it has been argued that per se laws are not a "panacea" (Walsh et al. 2004, p. 251). ${ }^{7}$ Moreover, the passage of a per se law does not guarantee public awareness. Becker's theory of crime is based on the assumption that individuals rationally weigh the expected costs and benefits of committing an offense (Becker 1968). If very few residents of per se states actually recognize that the probability of being convicted for drugged driving has

\footnotetext{
${ }^{6}$ For instance, in a letter to The Washington Post, Walsh and DuPont (2007) encouraged states to pass per se laws to combat "the epidemic of drugged driving." They went on to describe "prosecutors who are restricted by antiquated laws... and parents whose innocent children have been injured or killed" because of government inaction. California State Senator Lou Correa, who recently introduced a zero-tolerance drugged driving bill, is quoted on his website (http://sd34.senate.ca.gov/) as saying:
}

Driving under the influence of illegal drugs is dangerous and cannot be tolerated. Creating a zero tolerance drugged driving policy will equip law enforcement with the tools needed to keep our communities and roads safe...If you have drugs in your system you should not be on the road.

${ }^{7}$ See also Armentano (2013, p. 45), who argued that per se laws "may, in some instances, inadvertently criminalize behavior that poses no threat to traffic safety, such as the state-sanctioned private consumption of cannabis by adults." 
increased, then there is little reason to expect a change in behavior or an improvement in roadway safety. ${ }^{8}$

Although no previous study has examined the relationship between per se laws and traffic fatalities, the relationship between BAC laws and traffic fatalities has received considerable attention from economists. ${ }^{9}$ Using FARS data for the period 1982-1998 and a difference-indifferences approach, Dee (2001) found that the 0.08 BAC limit was associated with a 7 percent reduction in traffic fatalities. Eisenberg (2003), who used FARS data for the period 1982-2000 and an empirical approach similar to that used by Dee (2001), found that the 0.08 BAC limit was associated with an 11 percent reduction in traffic fatalities. In contrast, Freeman (2007), who used FARS data for the period 1980-2004, found little evidence that the BAC 0.08 limit was effective. Freeman (2007, p. 302) noted that over 30 states passed BAC 0.08 laws in the early

\footnotetext{
${ }^{8}$ More generally, Kleck et al. (2005, p. 627) argued that the "validity of rational decision-making theories does not require a perfect correspondence between contingencies and perceptions of them, but does require some correspondence if the theories are to have any explanatory or predictive power." Williams et al. (1980) found that perceptions of penalties reflect "public preferences as to appropriate sanctions for crimes and not necessarily actual knowledge of statutory penalties" (p. 105). A number of studies have, in fact, failed to find evidence of a relationship between dramatic, well-publicized changes in criminal sanctions and substance use (MacCoun and Reuter 2001; Dills et al. 2004; Hughes and Stevens 2010). Moreover, there is little evidence that prominent drug prevention programs such as Project D.A.R.E impact behavior (Ennett et al 1994; West and O'Neal 2004). Anderson (2010) and Anderson and Elsa (forthcoming) examined methamphetamine use among high school students after the introduction of advertising campaigns designed to curb demand. Despite anecdotal evidence to the contrary, these authors found little evidence that the campaign appreciably impacted the behavior of high school students.

${ }^{9}$ Jones (2005) found that the number of blood samples collected by police from Swedish motorists suspected of driving under the influence of drugs went up dramatically after a zero tolerance drugged driving law was introduced in 1999. Jones (2005, p. 321) concluded:
}

Sweden's new zero-concentration limit for scheduled drugs in the blood of drivers has stimulated police efforts to apprehend and prosecute DUID offenders...However, the problem of drug-impaired driving is far from solved. Those people who drive after taking illicit drugs are mostly criminal elements in society who lack a valid driving permit and whose police records show many previous convictions for drunk and/or drugged driving as well as other deviant behavior. Indeed, recidivism is close to $50-60 \%$ in these individuals so the zero-limit law has certainly not reduced DUID or functioned as a deterrent. 
2000s, but "alcohol-related traffic fatalities, as a percent of the total, were constant." $\mathrm{He}$ concluded that BAC 0.08 laws "have no measurable effects on traffic fatality rates" (Freeman 2007, p. 306). ${ }^{10}$

The evidence with regard to zero tolerance (ZT) drunk driving laws and traffic fatalities is also mixed. Several studies have found that ZT drunk driving laws, which make it illegal for individuals under the age of 21 to operate a motor vehicle with detectable levels of alcohol in their blood, are negatively related to traffic fatalities (Dee and Evans 2001; Eisenberg 2003; Voas et al. 2003). ${ }^{11}$ In contrast, Grant (2010) found that the estimated relationship between ZT drunk driving laws and daytime traffic fatalities was as strong as the relationship between ZT drunk driving laws and nighttime traffic fatalities. Because a substantial proportion of fatal crashes at night involve alcohol (Dee 1999), this pattern of results raises the possibility of omitted variable bias. Grant (2010, p. 769) concluded by noting that Prohibition, "the strongest zero tolerance law ever passed", had little effect on alcohol consumption. ${ }^{12}$

In the empirical analysis below, we are careful to distinguish between traffic fatalities that occurred at night and those that occurred during the day. In addition, we distinguish between traffic fatalities that occurred during the week and those that occurred on Friday night

\footnotetext{
${ }^{10}$ See also Young and Bielinska-Kwapisz (2006) who found that adopting a BAC 0.08 law was associated with an increase in traffic fatalities. French et al. (2009) found little evidence of a relationship between BAC 0.08 laws and motorcycle fatalities.

${ }^{11}$ See also Carpenter (2004) and Liang and Huang (2008) who examined the relationship between ZT drunk driving laws and alcohol consumption. Carpenter (2007) found that ZT drunk driving laws reduced property and nuisance crimes among 18- through 20-year-olds.

${ }^{12}$ Specifically, Grant (2010, p. 769) wrote:
}

Perhaps it is not surprising that zero tolerance laws are ineffective. After all, the strongest zero tolerance law ever passed —Prohibition — had a relatively small effect on alcohol consumption in the long term, according to Dills, Jacobson, and Miron (2005). 
through Monday morning. The percentage of drivers who test positive for marijuana and other controlled substances is highest at night and on weekends (Compton and Berning 2009).

Presumably, if per se laws reduce drugged driving, then their impact should be most pronounced during these times.

\section{ESTIMATION}

As noted in the introduction, information on traffic fatalities comes from the Fatality Analysis Reporting System (FARS), which is produced by the National Highway Traffic Safety Administration. The FARS data represent a census of all fatal injuries resulting from motor vehicle accidents in the United States. Information on the details of each accident and whether alcohol was involved comes from a variety of sources including police reports, driver licensing files, vehicle registration files, state highway department data, emergency medical services records, medical examiner reports, toxicology reports and death certificates. ${ }^{13}$

Our analysis covers the years 1990-2010. During this period, 17 states adopted a per se drugged driving law. We begin by estimating the following equation:

$$
\ln \left(\text { Traffic Fatalities }_{s t}\right)=\beta_{0}+\beta_{1} \text { Per se law } w_{s t}+v_{s}+w_{t}+\varepsilon_{s t}
$$

where Traffic Fatalities $_{s t}$ is equal to the number of traffic fatalities per 100,000 population of state $s$ in year $t^{14}$ The variable Per se lawst is an indicator for whether a per se law was in effect.

\footnotetext{
${ }^{13}$ Additional information on how the FARS data are collected is available at: http://www.nhtsa.gov/FARS.

${ }^{14}$ Population data come from the National Cancer Institute and are available at: http://seer.cancer.gov/popdata/index.html. Appendix Table 1 presents means, standard deviations, and definitions of the dependent variables used in the analysis.
} 
The coefficient of interest, $\beta_{1}$, represents the effect of these laws on traffic fatalities. State fixed effects, represented by the vector $v_{s}$, capture the influence of time-invariant factors at the state level. Year fixed effects, represented by the vector $w_{t}$, capture the influence of nationwide shocks to traffic fatalities.

Next, we add a set of controls to the estimating equation, represented by the vector $\boldsymbol{X}_{s t}$ :

$$
\ln \left(\text { Traffic Fatalities }_{s t}\right)=\beta_{0}+\beta_{1} \text { Per se law } w_{s t}+\boldsymbol{X}_{s t} \beta_{2}+v_{s}+w_{t}+\varepsilon_{s t} .
$$

Previous studies provide evidence that graduated driver licensing regulations and stricter seatbelt laws lead to fewer traffic fatalities (Cohen and Einav 2003; Dee et al. 2005; Freeman 2007; Carpenter and Stehr 2008). Other studies have examined the effects of speed limits (Ledolter and Chan 1996; Farmer et al. 1999; Hanssen 2000; Greenstone 2002; Dee and Sela 2003), administrative license revocation laws (Freeman 2007), BAC laws (Dee 2001; Eisenberg 2003; Young and Bielinska-Kwapisz 2006; Freeman 2007), zero tolerance drunk driving laws (Voas et al. 2003; Carpenter 2004; Liang and Huang 2008; Grant 2010), beer taxes (Chaloupka et al. 1991; Ruhm 1996; Dee 1999; Young and Likens 2000; Young and Bielinska-Kwapisz 2006), the legalization of medical marijuana (Anderson et al. 2013), marijuana decriminalization (Chaloupka and Laixuthai 1997), and cellphone/texting bans (Kolko 2009; Abouk and Adams 2013). In addition to these state-level policies that could potentially be correlated with per se laws and traffic fatalities, we include the mean age of the driver population in state $s$ and year $t$, 
the unemployment rate, real per capita income, and vehicle miles driven per licensed driver in the vector $\boldsymbol{X}_{\text {st. }}{ }^{15}$

Finally, our preferred specification includes state-specific linear time trends to our model, represented by $\Theta_{s} \cdot t$ :

$$
\ln (\text { Traffic Fatalities } \text { St })=\beta_{0}+\beta_{1} \text { Per se law } w_{s t}+\boldsymbol{X}_{s t} \beta_{2}+v_{s}+w_{t}+\Theta_{s} \cdot t+\varepsilon_{s t} .
$$

State-specific linear time trends control for state-level factors that evolve at a constant rate over time (e.g., sentiment towards drugged driving). All models are estimated using ordinary least squares and observations are weighted using the population in state $s$ at time $t$. Standard errors are corrected for clustering at the state level (Bertrand et al. 2004). ${ }^{16}$

Because previous studies have shown that drugged driving rates are highest at night and on weekends, we estimate (3), our preferred specification, replacing Traffic Fatalities st $_{\text {with }}$ the following alternative dependent variables: Fatalities Weekdays $s_{s}$, Fatalities Weekends $s_{s t}$,

\footnotetext{
${ }^{15}$ Appendix Table 2 presents means, standard deviations, and definitions of the independent variables used in the analysis. Information on graduated driver licensing laws and seatbelt requirements is available from Cohen and Einav (2003), Dee et al. (2005), and the Insurance Institute for Highway Safety (iihs.org). Information on administrative license revocation laws and BAC limits is available from Freeman (2007). Data on beer taxes are from the Brewers Almanac, an annual publication produced by the Beer Institute. Data on whether texting while driving was banned and whether using a handheld cellphone while driving was banned are from www.handsfreeinfo.com. Mean age in state $s$ and year $t$ was calculated using U.S. Census data, and information on vehicle miles driven per licensed driver is from Highway Statistics, an annual publication produced by the U.S. Department of Transportation. The unemployment and income data are from the Bureau of Labor Statistics and the Bureau of Economic Analysis, respectively. Data on decriminalization laws are from Model (1993) and Scott (2010).

${ }^{16}$ Controlling for state fixed effects, year fixed effects, and state-specific linear time trends is standard in the literature on traffic fatalities. See, for instance, Dee et al. (2005), Miron and Tetelbaum (2009), and Dills (2010). The estimates reported below are more precise if we do not correct for clustering at the state level. For instance, the standard error of our preferred estimate in column (4) of Table 2 goes from .023 to .015 if we do not correct for clustering. We also used the wild cluster bootstrap method proposed by Cameron et al. (2008) to check the precision of our estimates. The results were very similar to those reported in the paper.
} 
Fatalities Daytime $_{\text {st }}$, and Fatalities Nighttime st. $^{17}$ In addition, we estimate (3) replacing Traffic Fatalities $_{s t}$ with: Fatalities Males $s$, Fatalities Females Ft, $_{\text {, }}$ and a series of fatality rates corresponding to specific age groups (i.e., 15 through 19 years of ages, 20 through 29 years of age, 30 through 39 years of age, etc.). ${ }^{18}$ Driving under the influence of illicit drugs is especially prevalent among teenagers and young adults (Lacey et al. 2007; O'Malley and Johnston 2007; Substance Abuse and Mental Health Services Administration 2011), suggesting the relationship between adopting a per se standard and traffic fatalities should be strongest when we focus on these groups. The ONDCP has emphasized the problem of drugged driving among teenagers and young adults (ONDCP 2010, 2011a, 2012) and has issued a toolkit for parents containing activities "designed to raise awareness about drugged driving" (ONDCP 2011b, p. 2).

\section{RESULTS}

\subsection{The relationship between per se laws and traffic fatalities}

Figure 1 presents traffic fatality trends for states that adopted a per se law during the period 1990-2010. The vertical lines represent the years in which these laws came into effect. Figure 1 also shows the average trend for states that did not adopt a per se law. Although Figure 1 provides little evidence that per se laws reduce traffic fatalities, omitted factors could have

\footnotetext{
${ }^{17}$ Following Dee (2001), Fatalities Weekdays $s_{s t}$ is defined as the traffic fatality rate between 6 A.M. on Mondays to 5:59 P.M. on Fridays per 100,000 population in state $s$ and year $t$; Fatalities Weekends $s_{s t}$ is equal to the traffic fatality rate between 6 P.M. on Fridays and 5:59 A.M. on Mondays per 100,000 population in state $s$ and year $t$; Fatalities Daytime $_{s t}$ is equal to the traffic fatality rate between 6 A.M. and 5:59 P.M per 100,000 population in state $s$ and year $t$; Fatalities Nighttime $_{s t}$ is equal to the traffic fatality rate between 6 P.M. and 5:59 A.M per 100,000 population in state $s$ and year $t$.

${ }^{18}$ Fatalities $_{\text {Males }}$ is is equal to the traffic fatality rate per 100,000 males in state $s$ and year $t$. Fatalities Females is equal to the traffic fatality rate per 100,000 females in state $s$ and year $t$. The fatality rates by age group are rates per the relevant state-by-age populations.
} 
masked their effects. For instance, traffic fatalities were falling in most states prior to 2008 but the economic downturn appears to have accelerated this trend. ${ }^{19}$

Estimates of the relationship between per se laws and traffic fatalities are presented in Table 2. As predicted by the Beckerian model of crime (Becker 1968), we find evidence of a negative relationship between per se laws and traffic fatalities in the cross section. Specifically, the estimate in column (1) is negative and large, but not statistically significant. If taken at face value, it would suggest that the adoption of a per se law leads to a 10.3 percent $\left(\mathrm{e}^{-0.109}-1=-\right.$ $0.103)$ decrease in the traffic fatality rate.

When state and year fixed effects are included on the right-hand side, the adoption of a per se law is associated with a (statistically insignificant) 0.9 percent decrease in the traffic fatality rate. When the state-level controls are included, the estimate of $\beta_{1}$ becomes positive: the adoption of a per se law is associated with a (statistically insignificant) 2.4 percent increase in the traffic fatality rate. Finally, when we include state-specific linear time trends, the adoption of a per se law is associated with a (statistically insignificant) 1.9 percent increase in the traffic fatality rate. This estimate, however, is not precise: its standard error is equal to .023 and the lower bound of the $90 \% \mathrm{CI}$ is equal to -.019. Given this imprecision, we cannot rule out the possibility that per se laws reduce traffic fatalities. ${ }^{20}$

\footnotetext{
${ }^{19}$ Cotti and Tefft (2011) provide evidence with regard to the effect of the "Great Recession" of 2008-2009 on traffic fatalities.

${ }^{20}$ Regressing the log of traffic fatalities on the state fixed effects, year fixed effects, and state-specific linear trends, yields an R-squared of .973, suggesting that this imprecision may, in part, be due to a lack of within-state variation in traffic fatalities.
} 
It is possible that per se laws become more effective over time as the necessary apparatus for enforcement is put into place. To explore this issue, we replace the variable Per se lawst with an indicator for the year of the law change and five lags. The estimates are shown in Table 3.

With or without state-specific time trends, there is a small, statistically insignificant reduction in traffic fatalities the year in which the law changed and the first full year after implementation. While the remaining lags are positive, they are jointly statistically indistinguishable from zero. After 5 full years, and controlling for state-specific linear time trends, the adoption of a per se law is associated with a 6.4 percent increase in traffic fatalities. ${ }^{21}$

In the final column of Table 3, we include three leads of Per se lawst. Adding leads to the model provides a simple check for whether traffic fatality trends in treated and control states differed systematically prior to the adoption of per se laws. While the coefficients of the leads are uniformly positive, none are statistically significant, suggesting the common trends assumption holds. ${ }^{22}$ It should be noted, however, that the passage of a per se law could presage an increase in drugged driving or could be correlated with other difficult-to-observe determinants of traffic fatalities.

Table 4 presents estimates of the relationship between per se laws and traffic fatalities by the day of the week and the time of day. Because drivers are more likely to test positive for

\footnotetext{
${ }^{21}$ There is a substantial literature on the relationship between the use of marijuana and alcohol. In fact, a number of credible studies have found evidence suggesting that marijuana and alcohol are substitutes (DiNardo and Lemieux 2001; Crost and Guerrero 2012; Anderson et al. 2013; Kelly and Rasul. 2014). Although statistically insignificant, these estimates provide some evidence that, after 4 or 5 years, the adoption of per se laws could actually lead to an increase in traffic fatalities. One possible explanation for this result is that, because they reduce the relative cost of drunk driving, per se laws may lead to more alcohol-related accidents. To test this hypothesis, we estimated the relationship between per se laws and traffic fatalities resulting from accidents where at least one driver had a positive blood alcohol concentration. We found no evidence to suggest that per se laws increase alcohol-related traffic fatalities. Results were similar when estimating the relationship between per se laws and traffic fatalities resulting from accidents where at least one driver had a blood alcohol concentration greater than or equal to 0.10 .

${ }^{22}$ We can reject the hypothesis that the leads are jointly significant.
} 
illicit drugs on nights and on weekends (Compton and Berning 2009), it is important to distinguish between weekday and weekend traffic fatalities and between daytime and nighttime traffic fatalities. The estimates in Table 4 suggest that the adoption of a per se law is associated with small increases in the traffic fatality rate on weekdays, weekends, during the daytime, and during the nighttime. However, none of these estimates are statistically significant.

Up to this point, we have not distinguished between drivers based on age or gender, raising the possibility that the effects of per se laws on demographic subgroups have gone undetected. Table 5 illustrates estimates of the relationship between per se laws and traffic fatalities by age group. The potential for per se laws to affect the behavior of teenagers and young adults is of particular interest given the ONDCP's focus on these groups (ONDCP 2011b).

Among 15- through 19-year-olds, the estimate of $\beta_{l}$ is negative, but is not statistically significant at conventional levels. ${ }^{23}$ Of the remaining estimates, 4 out of 5 are positive and only one is statistically significant. The adoption of a per se law is associated with a 6.3 percent increase in the traffic fatality rate of individuals over the age of 60 , and this estimate is statistically significant at the 0.10 level.

There is evidence that males are more likely to drive under the influence of a controlled substance than females (National Household Survey on Drug Abuse 2002). However, the adoption of a per se law is not associated with a statistically significant reduction in traffic fatalities among males (Table 6). In fact, it is associated with a (statistically insignificant) 2.0

\footnotetext{
${ }^{23}$ When our focus is restricted to traffic fatalities among drivers ages $15-19$, we code South Dakota as if it were "treated." South Dakota, whose law went into effect on July 1, 1998, has a per se drugged driving law that applies only to individuals under the age of 21 .
} 
percent increase in male traffic fatalities. The adoption of a per se law is also associated with a (statistically insignificant) 2.8 percent increase in traffic fatalities among females. ${ }^{24}$

\subsection{Interstate Heterogeneity}

Thirteen of the states that enacted per se laws between 1990 and 2010 also had an active Drug Recognition Expert (DRE) program. ${ }^{25}$ DRE programs are designed to train officers to recognize drug impairment in drivers and to guide analyses of biological specimens when the presence of drugs other than alcohol is expected (Lacey et al. 2010). These extensive training and certification programs are also designed to teach officers about symptoms of impairment that could be used to determine the type of drug a driver has been using (Lacey et al. 2010). ${ }^{26}$ If drug intoxication is suspected, a blood or urine sample is submitted to a laboratory for confirmation (National Council on Alcoholism and Drug Dependence 2012). In a recent review of per se laws in the United States, DRE programs were characterized as a potentially important complement to per se legislation (Lacey et al. 2010). ${ }^{27}$

The top panel in Table 7 presents estimates of the relationship between per se laws and traffic fatalities distinguishing between per se states that have an active DRE program and states

\footnotetext{
${ }^{24}$ Estimates of the relationship between per se laws and traffic fatalities by age and gender (e.g., 15- through 19year-old males and 15- through 19-year-old females) were qualitatively similar to those reported in Tables 5 and 6. These results are available from the authors upon request.

${ }^{25}$ The following states passed a per se law during the period 1990-2010 and had an active DRE program as of 2010: Arizona, Delaware, Georgia, Indiana, Iowa, Kentucky, Minnesota, Nevada, North Carolina, Pennsylvania, Rhode Island, Utah, and Wisconsin (Lacey et al. 2010).

${ }^{26}$ From a practical standpoint, DRE officers may be called in for their expertise either before or after an arrest is made (Lacey et al. 2010).

${ }^{27}$ Some prosecutors have argued that DRE programs and officers make it more likely to obtain a guilty plea when a driver is arrested for suspicion of drugged driving (Lacey et al. 2010). However, even in states with large DRE programs, many cases go through the evidential and adjudicative process based only on testimony from the initial arresting officer (Lacey et al. 2010).
} 
that do not. ${ }^{28}$ There is little evidence to support the hypothesis that per se laws accompanied by an active DRE program reduce traffic fatalities.

Per se laws also vary with regard to sanctions. The middle panel of Table 7 presents estimates of the relationship between per se laws and traffic fatalities distinguishing between per se states that require mandatory imprisonment for a first offense and those that do not. ${ }^{29}$ The bottom panel of Table 7 presents estimates of the relationship between per se laws and traffic fatalities distinguishing between per se states that require a mandatory period of license revocation for a first offense and those that do not. ${ }^{30}$ When state-specific linear time trends are included, per se laws with mandatory imprisonment for a first offense are associated with a 6.2 percent increase in traffic fatalities. When state-specific linear time trends are included, per se laws with mandatory license revocation are positively associated with traffic fatalities; however, this estimate is statistically indistinguishable from zero. ${ }^{31}$

\footnotetext{
${ }^{28}$ While Rhode Island has a DRE program, only a handful of DRE officers have been employed at any given time. For example, there were 7 active DRE officers in Rhode Island at the beginning of 2007, but none at the end of the year (Lacey et al. 2010). We experimented with including Rhode Island among the states without a DRE program. This had little effect on the results presented in Table 7.

${ }^{29}$ The following states passed a per se law between 1990 and 2010 that required a mandatory imprisonment for a first offense: Arizona, Georgia, Iowa, Minnesota, Nevada, North Carolina, Ohio, and Utah (Lacey et al. 2010). The mandatory imprisonment lengths vary from a minimum of 24 hours (Arizona, Georgia, and North Carolina) to a maximum of three days (Ohio).

${ }^{30}$ The following states passed a per se law between 1990 and 2010 that required a mandatory period of license revocation for a first offense: Arizona, Delaware, Illinois, Indiana, Iowa, Kentucky, Minnesota, Nevada, North Carolina, Ohio, Rhode Island, Utah, Virginia, and Wisconsin (Lacey et al. 2010). The mandatory periods of license revocation vary from a minimum of 30 days (Indiana, Kentucky, and Rhode Island) to a maximum of 1 year (Delaware, North Carolina, and Virginia).

${ }^{31}$ We also examined the relationship between per se laws and traffic fatalities distinguishing between zero tolerance states and states that set nonzero thresholds for controlled substances. There was no evidence to suggest that zero tolerance per se laws are effective at reducing traffic fatalities. These results were omitted for the sake of brevity, but are available from the authors upon request.
} 


\subsection{Robustness checks}

In Table 8, we subject the findings discussed above to a series of sensitivity checks. For reference, the first column of Table 8 presents our preferred estimate from Table 2 that controls for the vector of covariates, state fixed effects, year fixed effects, and state-specific linear time trends. In the second column, we restrict our attention to states that adopted a per se law between 1990 and 2010 and states with which they shared a border. The estimated relationship between per se laws and traffic fatalities is positive, small in magnitude, and nowhere near statistically significant.

In the remaining columns, we consider three alternative dependent variables. First, we use the traffic fatality rate per 100,000 licensed drivers in state $s$ and year $t$ instead of Traffic Fatalities st. $^{32}$ Second, we use the traffic fatality rate per vehicle miles traveled. ${ }^{33}$ Lastly, we consider a logistic transformation often used by researchers working in this area (e.g. Ruhm 1996; Young and Likens 2000; Dills 2010). ${ }^{34}$ Regardless of the dependent variable used, there is little evidence to support the hypothesis that per se laws reduce traffic fatalities. Nevertheless, it is possible that per se laws are adopted in response to changing attitudes towards drugged driving or other difficult-to-observe determinants of traffic fatalities.

To further investigate this issue, we turned to a synthetic control approach (Abadie et al. 2010). Specifically, for each per se state we created a weighted set of control states using pre-

\footnotetext{
${ }^{32}$ Eisenberg (2003) used a similarly-defined dependent variable.

${ }^{33}$ Abouk and Adams (2013) examined the effect of texting bans on the traffic fatality rate per vehicle miles traveled as a robustness check.

${ }^{34}$ The log-odds ratio of traffic fatalities takes into account the discrete nature of a traffic fatality at the individual level (Ruhm 1996).
} 
treatment trends in variables that predict traffic fatalities at the state level. ${ }^{35}$ Figure 2 shows traffic fatality trends for each per se state and their synthetic counterfactual. The pre-treatment trends are closely aligned, suggesting that the synthetic control approach effectively captures the determinants of traffic fatalities in each of the per se states. ${ }^{36}$ Figure 2 provides no clear, consistent visual evidence that per se laws reduce traffic fatalities.

Table 9 presents state-by-state synthetic control regression estimates. ${ }^{37}$ The estimated effect of passing a per se law is statistically indistinguishable from zero in 10 out of 15 regressions; it is positive and significant in 4 regressions; and it is negative and significant in only 1 regression. These results are generally consistent with those reported above. ${ }^{38}$

\section{CONCLUSION}

Per se drugged driving laws set thresholds for controlled substances in the body above which drivers are presumed to be impaired. They are intended to make the job of prosecuting drugged drivers easier, and supporters assert that they improve roadway safety (DuPont 2004;

\footnotetext{
${ }^{35}$ Three evenly spaced leads of the traffic fatality rate and the covariates listed in Appendix Table 2 were used to construct the weighted set of control states.

${ }^{36}$ Arizona is not shown in Figure 2 because due to a lack of pre-treatment data; Kentucky is not shown due to a lack of post-treatment data.

${ }^{37}$ For other research that has implemented the Abadie et al. (2010) procedure within a regression context, see Nonnemaker et al. (2011), Brown et al. (2014), and Green et al. (2014). While we take the standard approach of weighting our regressions using the synthetic control weights, we also followed Nonnemaker et al. (2011) and experimented with giving equal weight to the controls states chosen by the matching procedure. These results also provided little evidence that per se laws were successful at reducing traffic fatalities.

${ }^{38}$ To investigate the within-state determinants of per se drugged driving laws, we regressed the unemployment rate in state $s$ and year $t$ on a per se indicator (equal to 1 the year the law came into effect, and equal to 0 otherwise), 6 leads of this indicator, and a set of controls that included state and year indicators. We also regressed the drug arrest rate in state $s$ and year $t$ on a per se indicator, 6 leads of this indicator, and the same set of controls. The coefficients of the per se leads were, with only one exception, statistically insignificant, suggesting that within-state changes in economic conditions and drug use do not predict the passage of per se drugged driving laws.
} 
Walsh and DuPont 2007; Dupont et al. 2012; Wood 2013). However, aside from anecdotal evidence, little is known about their effectiveness (Walsh et al. 2004).

Using data from the National Highway Traffic Safety Administration's Fatality Analysis Reporting System for the period 1990-2010, we examine the relationship between per se drugged driving laws and traffic fatalities. Estimates of this relationship are small and statistically indistinguishable from zero, but imprecise. For instance, according to our preferred specification, the adoption of a per se law is associated with a (statistically insignificant) 1.9 percent increase in the traffic fatality rate. The standard error of this estimate is large, and the lower bound of the $90 \%$ CI is equal to -.019. Given this imprecision, we cannot rule out the possibility that per se laws are effective.

A number of state legislatures have recently considered bills that would make it illegal to operate a motor vehicle with drugs (or drug metabolites) in the system (Ferner 2013b; Downs 2014; Krantz 2014; Malone 2014). If these bills are enacted, it may be possible to produce more precise, reliable estimates of the relationship between per se drugged driving laws and traffic fatalities. Until then, any assertion about their effectiveness or lack thereof should be viewed with skepticism.

\section{REFERENCES}

Abadie, Alberto, Alexis Diamond and Jens Hainmueller. 2010. "Synthetic Control Methods for Comparative Case Studies: Estimating the Effect of California's Tobacco Control Program." Journal of the American Statistical Association 105: 493-505.

Abouk, Rahi and Scott Adams. 2013. "Texting Bans and Fatal Accidents on Roadways: Do they Work? Or Do Drivers Just React to Announcements of Bans? American Economic Journal: Applied Economics 5(2): 179-199. 
Anderson, D. Mark. 2010. "Does Information Matter? The Effect of the Meth Project on Meth Use among Youths." Journal of Health Economics 29: 732-742.

Anderson, D. Mark and David Elsea. Forthcoming. "The Meth Project and Teen Meth Use: New Estimates from the National and State Youth Risk Behavior Surveys." Health Economics.

Anderson, D. Mark, Benjamin Hansen and Daniel I. Rees. 2013. "Medical Marijuana Laws, Traffic Fatalities, and Alcohol Consumption." Journal of Law and Economics 56: 333-369.

Anderson, D. Mark and Daniel I. Rees. 2014. "The Legalization of Recreational Marijuana: How Likely is the Worst-Case Scenario?" Journal of Policy Analysis and Management 33: 221-232.

Apel, Robert. 2013. "Sanctions, Perceptions, and Crime: Implications for Criminal Deterrence Journal of Quantitative Criminology 29: 67-101

Asbridge, Mark, Jill Hayden and Jennifer Cartwright. 2012. "Acute Cannabis Consumption and Motor Vehicle Collision Risk: Systematic Review of Observational Studies and MetaAnalysis." British Medical Journal 344: e536.

Armentano, Paul. 2013. "Should Per Se Limits Be Imposed For Cannabis? Equating Cannabinoid Blood Concentrations with Actual Driver Impairment: Practical Limitations and Concerns." Humboldt Journal of Social Relations 35: 45-55.

Becker, Gary. 1968. "Crime and Punishment: An Economic Approach." Journal of Political Economy 76: 169-217.

Bertrand, Marianne, Esther Duflo and Sendhil Mullainathan. 2004. "How Much Should We Trust Differences-in-Differences Estimates?" Quarterly Journal of Economics 119: 249276.

Botticelli, Michael. 2014. "Preventing Drugged Driving is as Important as Preventing Drunk Driving." Available at: http://www.whitehouse.gov/blog/2014/12/02/preventing-drugged-driving-importantpreventing-drunk-driving.

Brady, Joanne E. and Guohua Li. 2013. "Prevalence of Alcohol and Other Drugs in Fatally Injured Drivers." Addiction 108: 104-114.

Brown, Alexandra, J. Michael Collins, Maximilian Schmeiser and Carly Urban. 2014. "State Mandated Financial Education and the Credit Behavior of Young Adults." Finance and Economics Discussion Series Paper, Divisions of Research \& Statistics and Monetary Affairs, Federal Reserve Board, Washington, D.C.

Burian, Scott, Anthony Liguori and John Robinson. 2002. "Effects of Alcohol on Risk-Taking 
During Simulated Driving." Human Psychopharmacology 17: 141-150.

Cameron, Colin, Jonah Gelbach and Douglas Miller. 2008. "Bootstrap-Based Improvements for Inference with Clustered Errors." Review of Economics and Statistics 90: 414-427.

Carpenter, Christopher. 2004. "How do Zero Tolerance Drunk Driving Laws Work?” Journal of Health Economics 23: 61-83.

Carpenter, Christopher. 2007. "Heavy Alcohol Use and Crime: Evidence from Underage DrunkDriving Laws." Journal of Law and Economics 50: 539-557.

Carpenter, Christopher and Mark Stehr. 2008. "The Effects of Mandatory Seatbelt Laws on Seatbelt Use, Motor Vehicle Fatalities, and Crash-Related Injuries among Youths." Journal of Health Economics 27: 642-662.

Chaloupka, Frank and Adit Laixuthai. 1997. "Do Youths Substitute Alcohol and Marijuana? Some Econometric Evidence.” Eastern Economic Journal 23: 253-275.

Chaloupka, Frank, Henry Saffer and Michael Grossman. 1991. "Alcohol Control Policies and Motor Vehicle Fatalities.” NBER Working Paper No. 3831.

Cohen, Alma and Liran Einav. 2003. "The Effects of Mandatory Seat Belt Laws on Driving Behavior and Traffic Fatalities." Review of Economics and Statistics 85: 828-843.

Compton, Richard and Amy Berning. 2009. "Results of the 2007 National Roadside Survey of Alcohol and Drug Use by Drivers." Washington, D.C.: National Highway Traffic Safety Administration.

Cordova, Charles R. Jr. 2007. "DWI and Drugs: A Look at the Per Se Laws for Marijuana." Nevada Law Journal 7: Article 15.

Cotti, Chad and Nathan Tefft. 2011. "Decomposing the Relationship Between Macroeconomic Conditions and Fatal Car Crashes During the Great Recession: Alcohol- and NonAlcohol-Related Accidents." Bates College, Working Paper.

Crost, Benjamin and Santiago Guerrero. 2012. "The Effect of Alcohol Availability on Marijuana Use: Evidence from the Minimum Legal Drinking Age." Journal of Health Economics 31: 112-121.

Crost, Benjamin and Daniel I. Rees. 2012. "The Minimum Legal Drinking Age and Marijuana Use: New Estimates from the NLSY97." Journal of Health Economics 31: 112-121.

Dee, Thomas. 1999. "State Alcohol Policies, Teen Drinking and Traffic Fatalities." Journal of Public Economics 72: 289-315.

Dee, Thomas. 2001. "Does Setting Limits Save Lives? The Case of 0.08 BAC Laws." Journal 
of Policy Analysis and Management 20: 111-128.

Dee, Thomas and William Evans. 2001. "Teens and Traffic Safety.” In J. Gruber (Ed.), An Economic Analysis of Risky Behavior Among Youths, The University of Chicago Press, Chicago, IL.

Dee, Thomas, David Grabowski and Michael Morrisey. 2005. "Graduated Driver Licensing and Teen Traffic Fatalities.” Journal of Health Economics 24: 571-589.

Dee, Thomas and Rebecca Sela. 2003. "The Fatality Effects of Highway Speed Limits by Gender and Age.” Economics Letters 79: 401-408.

DeSimone, Jeffrey and Matthew Farrelly. 2003. "Price and Enforcement Effects on Cocaine and Marijuana Demand." Economic Inquiry 41: 98-115.

Dills, Angela. 2010. "Social Host Liability for Minors and Underage Drunk-Driving Accidents." Journal of Health Economics 29: 241-249.

Dills, Angela, Mireille Jacobson and Jeffrey Miron. 2005. "The Effect of Alcohol Prohibition on Alcohol Consumption: Evidence from Drunkenness Arrests." Economics Letters 86: 2 $79-284$.

DiNardo, John and Thomas Lemieux. 2001. "Alcohol, Marijuana, and American Youth: The Unintended Consequences of Government Regulation." Journal of Health Economics 20: 991-1010.

Downs, David. 2014. "Sober DUI Bill Dies in Sacramento; Alcoholics Go Untreated." East Bay Express, April 30. Available at: http://www.eastbayexpress.com/LegalizationNation/archives/2014/04/30/sober-dui-billdies-in-sacramento-alcoholics-go-untreated.

Dupont, Robert L. 2004. "Drugs and Driving." USA Today. October 28.

DuPont, Robert, Robert Voas, Michael Walsh, Corinne Shea, Stephen Talpins and Mark Neil. 2012. "The Need for Drugged Driving Per Se Laws: A Commentary." Traffic Injury Prevention.

Eisenberg, Daniel. 2003. "Evaluating the Effectiveness of Policies Related to Drunk Driving." Journal of Policy Analysis and Management 22: 249-274.

Elliot, Steve. 2012. "Washington Becomes $2^{\text {nd }}$ State in One Day to Legalize Marijuana." Toke of the Town. November 6. Available at:

http://www.tokeofthetown.com/2012/11/washington becomes 2nd state in one day to _legaliz.php. 
Ennett, Susan T., Nancy S. Tobler, Christopher Ringwalt and Robert L. Flewelling. 1994. "How Effective is Drug Abuse Resistance Education? A Meta-Analysis of Project DARE Outcome Evaluations.” American Journal of Public Health 84: 1394-1401.

Farmer, Charles, Richard Retting and Adrian Lund. 1999. "Changes in Motor Vehicle Occupant Fatalities After Repeal of the National Maximum Speed Limit." Accident Analysis and Prevention 31: 537-543.

Farrelly, Matthew, Jeremy Bray, Gary Zarkin, Brett Wendling and Rosalie Pacula. 1999. "The Effects of Prices and Policies on the Demand for Marijuana: Evidence from the National Household Surveys on Drug Abuse.” NBER Working Paper No. 6940.

Ferner, Matt. 2013a. "Marijuana DUI Bill Passes In Colorado Senate, Appears Poised To Become Law. The Huffington Post, May 7. Available at: http://www.huffingtonpost.com/2013/05/07/marijuana-dui-bill-

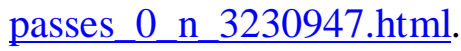

Ferner, Mattt. 2013b. "Too Stoned To Drive? Marijuana DUI Bill Passes Colorado House." The Huffington Post, May 2. Available at: http://www.huffingtonpost.com/2013/04/02/too-stoned-to-drive-marij n 3001016.html, $\underline{4 / 2 / 13}$.

Freeman, Donald. 2007. "Drunk Driving Legislation and Traffic Fatalities: New Evidence on BAC 08 Laws.” Contemporary Economic Policy 25: 293-308.

Freeman, David and Monica DyBuncio. 2011. "Drugged Driving Report Shows High Toll Among Young." CBS News. October 13. Available at: http://www.cbsnews.com/8301-504763_162-20119985-10391704.html

French, Michael, Gulcin Gumus and Jenny Homer. 2009. "Public Policies and Motorcycle Safety." Journal of Health Economics 28: 831-838.

Grant, Darren. 2010. "Dead on Arrival: Zero Tolerance Laws Don't Work.” Economic Inquiry 48: $756-770$.

Green, Colin, John Heywood and Maria Navarro. 2014. "Did Liberalising Bar Hours Decrease Traffic Accidents?” Journal of Health Economics 35: 189-198.

Greenstone, Michael. 2002. "A Reexamination of Resource Allocation Responses to the 65-mph Speed Limit.” Economic Inquiry 40: 271-278.

Hanssen, F. Andrew. 2000. "Speed Limit Laws: Does Speed Influence Accidents and Fatalities?" Montana Business Quarterly 38: 20-23.

Hartman, Rebecca and Marilyn Huestis. 2013. "Cannabis Effects on Driving Skills." Clinical Chemistry 59: 478-92. 
Hughes, Caitlin Elizabeth and Alex Stevens. 2010. "What Can we Learn from the Portuguese Decriminalization of Illicit Drugs?” British Journal of Criminology 50: 999-1022.

Ingold, John. 2013. "Colorado Legislature gives Final OK to Marijuana Driving Limit." The Denver Post, May 7. Available at: http://www.denverpost.com/ci 23189484/colorado-legislature-gives-final-ok-marijuanadriving-limit.

Jones, Alan. 2005. "Driving Under the Influence of Drugs in Sweden with Zero Concentration Limits in Blood for Controlled Substances." Traffic Injury Prevention 6: 317-322.

Kelly, Erin, Shane Drake and Joanne Ross. 2004. "A Review of Drug Use and Driving: Epidemiology, Impairment, Risk Factors and Risk Perceptions." Drug and Alcohol Review 23: 319-344.

Kelly, Elaine and Imran Rasul. 2014. "Policing Cannabis and Drug Related Hospital Admissions: Evidence from Administrative Records." Journal of Public Economics 112: 89-114.

Kerlikowske, R. Gil. 2012. "Guest Commentary: Driving High is a Threat to Public." The Denver Post. March 4. Available at: http://www.denverpost.com/opinion/ci_20083104.

Kleck, Gary, Brion Sever, Spencer Li and Marc Gertz. 2005. "The Missing Link in General Deterrence Research.” Criminology 43: 623-660.

Kolko, Jed. 2009. "The Effects of Mobile Phones and Hands-Free Laws on Traffic Fatalities." B.E. Journal of Economic Analysis and Policy (Contributions) 9: 1-26.

Krantz, Laura. 2014. "Drugged Driving Bill Dominates Senate Judiciary’s Agenda.” Vermont Bitz, April 26. Available at: http://www.vermontbiz.com/news/april/drugged-driving-bill-dominates-senatejudiciary\%E2\%80\%99s-agenda.

Lacey, John H., Tara Kelley-Baker, Debra Furr-Holden, Robert B. Voas, Eduardo Romano, Anthony Ramirez, Katharine Brainard, Christine Moore, Pedro Torres and Amy Berning. 2009. "2007 National Roadside Survey of Alcohol and Drug Use by Drivers: Drug Results.” Washington, D.C.: National Highway Traffic Safety Administration.

Lacey, John, Katharine Brainard and Samantha Snitow. 2010. "Drug Per Se Laws: A Review of Their Use in States.” Washington, D.C.: National Highway Traffic Safety Administration.

Ledolter, Johannes and K.S. Chan. 1996. "Evaluating the Impact of the 65 mph Maximum Speed Limit on Iowa Rural Interstates.” American Statistician 50: 79-85. 
Liang, Lan and Jidong Huang. 2008. "Go Out or Stay In? The Effects of Zero Tolerance Laws on Alcohol Use and Drinking and Driving Patterns among College Students." Health Economics 17: 1261-1275.

Leinwand, Donna. 2004. “Growing Danger: Drugged Driving.” USA Today. October 21. Available at: http://usatoday30.usatoday.com/news/nation/2004-10-21-cover-drugged-driving_x.htm.

MacCoun, Robert, Rosalie Pacula, Jamie Chriqui, Katherine Harris and Peter Reuter. 2009. "Do Citizens Know Whether Their State Has Decriminalized Marijuana? Assessing the Perceptual Component of Deterrence Theory." Review of Law and Economics 5: 347371.

MacCoun, Robert and Peter Reuter. 2001. "Evaluating Alternative Cannabis Regimes.” British Journal of Psychiatry. 178: 123-128.

MacDonald, Scott, Robert Mann, Mary Chipman, Basia Pakula, Pat Erickson, Andrew Hathaway and Peter MacIntyre. 2008. "Driving Behavior Under the Influence of Cannabis or Cocaine." Traffic Injury Prevention 9: 190-194.

Malone, Patrick. 2014. "Bill Strengthening Drugged-Driving Laws Moves Forward Despite Concerns." Santa Fe New Mexican, February 11. Available at: http://www.santafenewmexican.com/news/legislature/bill-strengthening-drugged-drivinglaws-moves-forward-despite-concerns/article 66c3307c-8523-5bc8-9d1e93914505cc48.html.

Marczinski, Cecile, Emily Harrison and Mark Fillmore. 2008. "Effects of Alcohol on Simulated Driving and Perceived Driving Impairment in Binge Drinkers." Alcoholism: Clinical and Experimental Research 32: 1329-1337.

Miron, Jeffrey and Elina Tetelbaum. 2009. "Does the Minimum Legal Drinking Age Save Lives?” Economic Inquiry 47: 317-336.

Miranda, Nannette. 2013. "Drugged-Driving Bill Introduced by Sen. Correa Makes Any Detectable Amount Illegal." ABC News. February 19. Available at: http://abclocal.go.com/kabc/story?section=news/state\&id=8999069.

Model, Karyn. 1993. “The Effect of Marijuana Decriminalization on Hospital Emergency Room Drug Episodes: 1975-1978." Journal of the American Statistical Association 88: 737-747.

National Alliance for Model State Drug Laws. 2014. "Standards for "Drugged Driving"Current State Statutes and Recently Proposed Legislation." Available at: http://www.namsdl.org/library/A00800EF-BE06-E88C-2476DA34509C47AA/.

National Council on Alcoholism and Drug Dependence. 2012. "Drugged Driving." Available at: 
http://www.ncadd.org/index.php/learn-about-drugs/drugged-driving.

Nonnemaker, James, Mark Engelen and Daniel Shive. 2011. "Are Methamphetamine Precursor Control Laws Effective Tools to Fight the Methamphetamine Epidemic?" Health Economics 20: 519-531.

Office of National Drug Control Policy. 2010. National Drug Control Strategy 2010. Rockville, MD: Office of National Drug Control Policy.

Office of the National Drug Control Policy. 2011a. "White House Drug Policy Director and Mothers Against Drug Driving Unite to Combat Drugged Driving; Call on Parents to Act to Reduce Significant Public Safety Threat.” Available at: http://www.whitehouse.gov/ondcp/news-releases-remarks/white-house-drug-policydirector-and-mothers-against-drunk-driving-unite.

Office of the National Drug Control Policy. 2011b. "Teen Drugged Driving: Parent, Coalition and Community Group Activity Guide." Available at: http://www.whitehouse.gov/sites/default/files/ondcp/issues-content/druggeddriving/ondep teendruggeddrivingtoolkit 41613 final.pdf.

Office of the National Drug Control Policy. 2012. "Director Kerlikowske Remarks to National Sheriffs Association on Criminal Justice Reform." Available at: http://www.whitehouse.gov/ondcp/news-releases-remarks/director-kerlikowske-remarksto-national-sheriffs-association-on-criminal-justice-reform.

O’Malley, Patrick and Lloyd Johnston. 2007. "Drugs and driving by American high school seniors, 2001-2006." Journal of Studies on Alcohol and Drugs 68: 834-842.

Pacula, Rosalie. 1998. "Does Increasing the Beer Tax Reduce Marijuana Consumption?" Journal of Health Economics 17: 557-585.

Ramaekers, J., H. Robbe and J. O'hanlon. 2000. "Marijuana, Alcohol and Actual Driving Performance." Human Psychopharmacology 15: 551-558.

Robbe, Hindrick and James O'Hanlon. 1993. "Marijuana and Actual Driving Performance." Washington, D.C.: U.S. Department of Transportation, National Highway Traffic Safety Administration.

Ronen, Adi, Pnina Gershon, Hana Drobiner, Alex Rabinovich, Rachel Bar-Hamburger, Raphael Mechoulam, Yair Cassuto and David Shinar. 2008. "Effects of THC on Driving Performance, Physiological State and Subjective Feelings Relative to Alcohol." Accident Analysis and Prevention 40: 926-934.

Ruhm, Christopher. 1996. "Alcohol Policies and Highway Vehicle Fatalities." Journal of Health Economics 15: 435-454. 
Scott, Emilee Mooney. 2010. "Marijuana Decriminalization.” Office of Legislative Research Report. Available at: http://www.cga.ct.gov/2010/rpt/2010-R-0204.htm.

Sensible Washington. 2012. "Moving Forward." Sensible Washington, November 6. Available at: http://sensiblewashington.org/blog/.

Sewell, R. Andrew, James Poling and Mehmet Sofuoglu. 2009. "The Effect of Cannabis Compared with Alcohol on Driving" The American Journal on Addictions. 18: 185-193.

Spitzer, Gabriel. 2012. "Will Legal Marijuana Make our Roads More Dangerous?" KPLU News, October 8. Available at: http://www.kplu.org/post/will-legal-marijuana-make-our-roads-more-dangerous.

Substance Abuse and Mental Health Services Administration. 2011. "Results from the 2010 National Survey on Drug Use and Health: Summary of National Findings." Rockville, MD: Center for Behavioral Health Statistics and Quality.

Voas, Robert, A. Scott Tippetts and James Fell. 2003. "Assessing the Effectiveness of Minimum Legal Drinking Age and Zero Tolerance Laws in the United States." Accident Analysis and Prevention 35: 579-587.

Walsh, Michael, Johan Gier, Asbjorg Christopherson and Alain Verstraete. 2004. "Drugs and Driving." Traffic Injury Prevention 5: 241-253.

Walsh, Michael J. and Robert L. DuPont. 2007. “The Drugged Driving Epidemic.” Washington Post. June 17. Available at: http://www.washingtonpost.com/wpdyn/content/article/2007/06/15/AR2007061501895.html.

West, Steven L. and Keri K. O'Neal. 2004. "Project D.A.R.E. Outcome Effectiveness Revisited." American Journal of Public Health 94: 1027-1029.

Westall, Sylvia. 2010. “U.S. Says ‘Drugged Driving' Growing Threat” Reuters, March 9. Available at: http://www.reuters.com/article/2010/03/09/us-usa-drugs-idUSTRE6284W520100309.

White House. 2012a. "Drugged Driving." Office of National Drug Control Policy. Available at: http://www.whitehouse.gov/ondcp/drugged-driving.

Williams, Kirk, Jack Gibbs and Maynard Erickson. 1980. "Public Knowledge of Statutory Penalties: The Extent and Basis of Accurate Perception." Pacific Sociological Review 23: $105-128$. 
Williams, Jenny, Rosalie Pacula, Frank Chaloupka and Henry Wechsler. 2004. "Alcohol and Marijuana Use among College Students: Economic Complements or Substitutes?" Health Economics 13: 825-843.

Wyatt, Kristen and Gene Johnson. 2012. "With Marijuana Legal in Colorado and Washington, Police Worry About Stoned Driving." Huffington Post, November 15. Available at: http://www.huffingtonpost.com/2012/11/15/with-pot-legal-police-wor n 2136034.html.

Young, Douglas and Agnieszka Bielinska-Kwapisz. 2006. "Alcohol Prices, Consumption, and Traffic Fatalities.” Southern Economic Journal 72: 690-703.

Young, Douglas and Thomas Likens. 2000. "Alcohol Regulation and Auto Fatalities." International Review of Law and Economics 20: 107-126. 
Table 1. Per Se Drugged Driving Laws, 1990-2010

\begin{tabular}{lr} 
& Effective date \\
\hline Arizona & June 28, 1990 \\
Delaware & July 10, 2007 \\
Georgia & July 1, 2001 \\
Illinois & August 15, 1997 \\
Indiana & July 1, 2001 \\
Iowa & July 1, 1998 \\
Kentucky & July 15, 2010 \\
Michigan & September 30, 2003 \\
Minnesota & August 1, 2006 \\
Nevada & September 23, 2003 \\
North Carolina & December 1, 2006 \\
Ohio & August 17, 2006 \\
Pennsylvania & February 1, 2004 \\
Rhode Island & July 1, 2006 \\
Utah & May 2, 1994 \\
Virginia & July 1, 2005 \\
Wisconsin & December 19, 2003 \\
\hline Notes: Information on per se drugged driving laws is available from Lacey et al. (2010), \\
Armentano (2013), and the National Alliance for Model State Drug Laws (2014). Since \\
2010, Montana, Oklahoma, and Washington have enacted per se drugged driving laws. In \\
2013, the Colorado legislature passed HB 1325, under which having 5 or more nanograms \\
of THC per milliliter of blood gives rise to the "permissible inference" of driving while \\
impaired (Ferner 2013a; Ingold 2013). \\
\end{tabular}


Table 2. Per Se Drugged Driving Laws and Traffic Fatalities

\begin{tabular}{lcccc}
\hline & $(1)$ & $(2)$ & $(3)$ & $(4)$ \\
\hline Per se law & -0.109 & -0.009 & 0.024 & 0.019 \\
& $(0.100)$ & $(0.028)$ & $(0.026)$ & $(0.023)$ \\
$\mathrm{N}$ & 1071 & 1071 & 1071 & 1071 \\
$\mathrm{R}^{2}$ & 0.012 & 0.957 & 0.968 & 0.979 \\
& & & \\
Year FEs & No & Yes & Yes & Yes \\
State FEs & No & Yes & Yes & Yes \\
State covariates & No & No & Yes & Yes \\
State-specific trends & No & No & No & Yes \\
\hline *, statistically significant at $10 \%$ level; **, at 5\% level; ***, at 1\% level. & &
\end{tabular}

Notes: Each column represents the results from a separate regression. The dependent variable is equal to the natural $\log$ of total traffic fatalities per 100,000 population and the covariates are listed in Appendix Table 2. Regressions are weighted using state populations. Standard errors, corrected for clustering at the state level, are in parentheses. 
Table 3. The Timing of Per Se Drugged Driving Laws and Traffic Fatalities

\begin{tabular}{|c|c|c|c|}
\hline & (1) & (2) & (3) \\
\hline 3 years before per se law & $\ldots$ & $\ldots$ & $\begin{array}{c}0.027 \\
(0.021)\end{array}$ \\
\hline 2 years before per se law & $\cdots$ & .. & $\begin{array}{c}0.019 \\
(0.023)\end{array}$ \\
\hline 1 year before per se law & $\ldots$ & $\ldots$ & $\begin{array}{c}0.006 \\
(0.020)\end{array}$ \\
\hline Year of law change & $\begin{array}{c}-0.003 \\
(0.021)\end{array}$ & $\begin{array}{c}-0.015 \\
(0.014)\end{array}$ & $\begin{array}{l}-0.002 \\
(0.022)\end{array}$ \\
\hline 1 year after per se law & $\begin{array}{c}0.009 \\
(0.033)\end{array}$ & $\begin{array}{c}0.007 \\
(0.024)\end{array}$ & $\begin{array}{c}0.020 \\
(0.027)\end{array}$ \\
\hline 2 years after per se law & $\begin{array}{c}0.029 \\
(0.031)\end{array}$ & $\begin{array}{c}0.027 \\
(0.028)\end{array}$ & $\begin{array}{c}0.041 \\
(0.034)\end{array}$ \\
\hline 3 years after per se law & $\begin{array}{c}0.022 \\
(0.029)\end{array}$ & $\begin{array}{c}0.022 \\
(0.022)\end{array}$ & $\begin{array}{c}0.037 \\
(0.032)\end{array}$ \\
\hline 4 years after per se law & $\begin{array}{c}0.048 \\
(0.034)\end{array}$ & $\begin{array}{l}0.051 * \\
(0.026)\end{array}$ & $\begin{array}{l}0.067 * \\
(0.034)\end{array}$ \\
\hline $5+$ years after per se law & $\begin{array}{c}0.019 \\
(0.031)\end{array}$ & $\begin{array}{l}0.062 * \\
(0.034)\end{array}$ & $\begin{array}{l}0.081 * \\
(0.045)\end{array}$ \\
\hline p-value: joint significance of lags & 0.140 & 0.229 & 0.218 \\
\hline $\begin{array}{l}\mathrm{N} \\
\mathrm{R}^{2}\end{array}$ & $\begin{array}{c}1071 \\
0.968\end{array}$ & $\begin{array}{c}1071 \\
0.979\end{array}$ & $\begin{array}{l}1071 \\
0.979\end{array}$ \\
\hline $\begin{array}{l}\text { Year FEs } \\
\text { State FEs } \\
\text { State covariates } \\
\text { State-specific trends }\end{array}$ & $\begin{array}{l}\text { Yes } \\
\text { Yes } \\
\text { Yes } \\
\text { No }\end{array}$ & $\begin{array}{l}\text { Yes } \\
\text { Yes } \\
\text { Yes } \\
\text { Yes }\end{array}$ & $\begin{array}{l}\text { Yes } \\
\text { Yes } \\
\text { Yes } \\
\text { Yes }\end{array}$ \\
\hline
\end{tabular}

$*$, statistically significant at $10 \%$ level; ${ }^{* *}$, at $5 \%$ level; ${ }^{* * *}$, at $1 \%$ level.

Notes: Each column represents the results from a separate regression. The dependent variable is equal to the natural log of total traffic fatalities per 100,000 population and the covariates are listed in Appendix Table 2. In columns (1) and (2), the omitted category is $1+$ years before a per se law was adopted. In column (3), the omitted category is $3+$ years before a per se law was adopted. Regressions are weighted using state populations. Standard errors, corrected for clustering at the state level, are in parentheses. 
Table 4. Per Se Drugged Driving Laws and Traffic Fatalities by Day and Time

\begin{tabular}{lcccc}
\hline & $\begin{array}{c}\text { Fatalities } \\
\text { Weekdays }\end{array}$ & $\begin{array}{c}\text { Fatalities } \\
\text { Weekend }\end{array}$ & $\begin{array}{c}\text { Fatalities } \\
\text { Daytime }\end{array}$ & $\begin{array}{c}\text { Fatalities } \\
\text { Nighttime }\end{array}$ \\
\hline Per se law & 0.010 & 0.033 & 0.025 & 0.014 \\
& $(0.023)$ & $(0.030)$ & $(0.025)$ & $(0.028)$ \\
$\mathrm{N}$ & 1071 & 1071 & 1071 & 1071 \\
$\mathrm{R}^{2}$ & 0.970 & 0.961 & 0.967 & 0.966 \\
& & & & \\
Year FEs & Yes & Yes & Yes & Yes \\
State FEs & Yes & Yes & Yes & Yes \\
State covariates & Yes & Yes & Yes & Yes \\
State-specific trends & Yes & Yes & Yes & Yes \\
\hline
\end{tabular}

*, statistically significant at $10 \%$ level; **, at $5 \%$ level; ***, at $1 \%$ level.

Notes: Each column represents the results from a separate regression. The dependent variable is equal to the natural $\log$ of total traffic fatalities per 100,000 population and the covariates are listed in Appendix Table 2. Regressions are weighted using state populations. Standard errors, corrected for clustering at the state level, are in parentheses. 
Table 5. Per Se Drugged Driving Laws and Traffic Fatalities by Age

\begin{tabular}{lcccccc}
\hline & Fatalities & Fatalities & Fatalities & Fatalities & Fatalities & Fatalities \\
& $15-19$ & $20-29$ & $30-39$ & $40-49$ & $50-59$ & $60+$ \\
\hline Per se law & -0.042 & 0.044 & 0.029 & 0.018 & -0.006 & $0.061^{*}$ \\
& $(0.040)$ & $(0.027)$ & $(0.031)$ & $(0.030)$ & $(0.030)$ & $(0.033)$ \\
$\mathrm{N}$ & 1071 & 1071 & 1071 & 1071 & 1071 & 1071 \\
$\mathrm{R}^{2}$ & 0.915 & 0.940 & 0.943 & 0.939 & 0.876 & 0.921 \\
& & & & & & Yes \\
Year FEs & Yes & Yes & Yes & Yes & Yes & Yes \\
State FEs & Yes & Yes & Yes & Yes & Yes & Yes \\
State covariates & Yes & Yes & Yes & Yes & Yes & Yes \\
State-specific trends & Yes & Yes & Yes & Yes & &
\end{tabular}

Notes: Each column represents the results from a separate regression. The dependent variable is equal to the natural log of total traffic fatalities per 100,000 population and the covariates are listed in Appendix Table 2. Regressions are weighted using the relevant state-by-age populations. Standard errors, corrected for clustering at the state level, are in parentheses. 
Table 6. Per Se Drugged Driving Laws and Traffic Fatalities

\begin{tabular}{lcc} 
& by Gender & \\
\hline & $\begin{array}{c}\text { Fatalities } \\
\text { Males }\end{array}$ & $\begin{array}{c}\text { Fatalities } \\
\text { Females }\end{array}$ \\
\hline Per se law & 0.020 & 0.028 \\
& $(0.026)$ & $(0.026)$ \\
$\mathrm{N}$ & & \\
$\mathrm{R}^{2}$ & 1071 & 1071 \\
& 0.974 & 0.960 \\
Year FEs & & \\
State FEs & Yes & Yes \\
State covariates & Yes & Yes \\
State-specific trends & Yes & Yes \\
\hline *, statistically significant at 10\% level; **, at 5\% level; ***, at 1\% level.
\end{tabular}

Notes: Each column represents the results from a separate regression. The dependent variable is equal to the natural log of total traffic fatalities per 100,000 population and the covariates are listed in Appendix Table 2.

Regressions are weighted using the relevant state-by-sex populations.

Standard errors, corrected for clustering at the state level, are in parentheses. 
Table 7. Drug Recognition Expert Programs, Mandatory Imprisonment, and Mandatory License Revocation

\begin{tabular}{|c|c|c|c|}
\hline & $\begin{array}{c}\text { Traffic } \\
\text { Fatalities } \\
\end{array}$ & $\begin{array}{c}\text { Traffic } \\
\text { Fatalities } \\
\end{array}$ & $\begin{array}{c}\text { Traffic } \\
\text { Fatalities }\end{array}$ \\
\hline \multicolumn{4}{|l|}{ DRE Activity } \\
\hline Per se law with & 0.017 & 0.037 & 0.003 \\
\hline active DRE program & $(0.030)$ & $(0.032)$ & $(0.027)$ \\
\hline Per se law without active & -0.045 & 0.002 & 0.042 \\
\hline DRE program & $(0.038)$ & $(0.031)$ & $(0.033)$ \\
\hline $\mathrm{N}$ & 1071 & 1071 & 1071 \\
\hline $\mathrm{R}^{2}$ & 0.957 & 0.968 & 0.979 \\
\hline \multicolumn{4}{|l|}{$\begin{array}{l}\text { Mandatory Imprisonment } \\
\text { for } 1^{\text {st }} \text { Offense }\end{array}$} \\
\hline Per se law with mandatory & -0.009 & 0.015 & $0.060 *$ \\
\hline imprisonment & $(0.029)$ & $(0.032)$ & $(0.031)$ \\
\hline Per se le without mandatory & -0.009 & 0.030 & -0.014 \\
\hline imprisonment & $(0.040)$ & $(0.033)$ & $(0.025)$ \\
\hline $\mathrm{N}$ & 1071 & 1071 & 1071 \\
\hline $\mathrm{R}^{2}$ & 0.957 & 0.968 & 0.979 \\
\hline \multicolumn{4}{|l|}{ Mandatory License } \\
\hline \multicolumn{4}{|l|}{ Revocation for $1^{\text {st }}$ Offense } \\
\hline Per se law with mandatory & -0.012 & 0.019 & 0.036 \\
\hline license revocation & $(0.023)$ & $(0.025)$ & $(0.026)$ \\
\hline Per se law without mandatory & -0.004 & 0.034 & -0.028 \\
\hline license revocation & $(0.065)$ & $(0.050)$ & $(0.022)$ \\
\hline $\mathrm{N}$ & 1071 & 1071 & 1071 \\
\hline $\mathrm{R}^{2}$ & 0.957 & 0.968 & 0.979 \\
\hline Year FEs & Yes & Yes & Yes \\
\hline State FEs & Yes & Yes & Yes \\
\hline State covariates & No & Yes & Yes \\
\hline State-specific trends & No & No & Yes \\
\hline
\end{tabular}

*, statistically significant at $10 \%$ level; **, at $5 \%$ level; ***, at $1 \%$ level.

Notes: Each column within each panel represents a separate regression. The dependent variable is equal to the natural log of total traffic fatalities per 100,000 population and the covariates are listed in Appendix Table 2. Regressions are weighted using state populations. Standard errors, corrected for clustering at the state level, are in parentheses. 
Table 8. Robustness Checks

\begin{tabular}{|c|c|c|c|c|c|}
\hline & \multirow[b]{2}{*}{$\begin{array}{c}\text { Preferred } \\
\text { estimate from } \\
\text { Table } 2\end{array}$} & \multirow[b]{2}{*}{$\begin{array}{l}\text { Sample restricted to } \\
\text { per se states and } \\
\text { their neighbors }\end{array}$} & \multicolumn{3}{|c|}{ Alternative dependent variable transformations } \\
\hline & & & $\begin{array}{l}\text { Fatalities per } \\
\text { licensed driver } \\
\text { population }\end{array}$ & $\begin{array}{l}\text { Fatalities per } \\
\text { vehicle miles } \\
\text { traveled }\end{array}$ & $\begin{array}{c}\text { Logistic model } \\
\ln \left(\frac{\text { Traffic fatalities }_{s t}}{1-\text { Traffic fatalities }_{\text {st }}}\right)\end{array}$ \\
\hline Per se law & $\begin{array}{c}0.019 \\
(0.023)\end{array}$ & $\begin{array}{c}0.014 \\
(0.024)\end{array}$ & $\begin{array}{c}0.016 \\
(0.023)\end{array}$ & $\begin{array}{c}0.012 \\
(0.023)\end{array}$ & $\begin{array}{c}0.012 \\
(0.058)\end{array}$ \\
\hline $\mathrm{N}$ & 1071 & 798 & 1071 & 1071 & 1071 \\
\hline $\mathrm{R}^{2}$ & 0.979 & 0.981 & 0.975 & 0.961 & 0.950 \\
\hline Year FEs & Yes & Yes & Yes & Yes & Yes \\
\hline State FEs & Yes & Yes & Yes & Yes & Yes \\
\hline State covariates & Yes & Yes & Yes & Yes & Yes \\
\hline State-specific trends & Yes & Yes & Yes & Yes & Yes \\
\hline
\end{tabular}

Notes: Each column represents the results from a separate regression. In the first two columns, the dependent variable is equal to the natural log of total traffic fatalities per 100,000 population and these regressions are weighted using state populations. In the last three columns, the dependent variable is equal to the indicated measure. The regression in the third column is weighted using state licensed driver populations. The regression in the fourth column is weighted using state vehicle miles traveled. The regression in the fifth column is weighted based on the variance of the logodds ratio dependent variable (Ruhm 1996). The covariates are listed in Appendix Table 2. Standard errors, corrected for clustering at the state level, are in parentheses. 
Table 9. Synthetic Control Results

\begin{tabular}{|c|c|c|c|c|c|}
\hline \multirow{2}{*}{$\begin{array}{l}\text { Delaware } \\
\text { Per se law }\end{array}$} & & \multicolumn{2}{|l|}{ Georgia } & \multicolumn{2}{|l|}{ Illinois } \\
\hline & $\begin{array}{l}.019 \\
(.055)\end{array}$ & Per se law & $\begin{array}{l}.061 \\
(.063)\end{array}$ & Per se law & $\begin{array}{l}-.131 \\
(.113)\end{array}$ \\
\hline $\mathrm{N}$ & 210 & $\mathrm{~N}$ & 189 & $\mathrm{~N}$ & 210 \\
\hline Indiana & & Iowa & & Michigan & \\
\hline Per se law & $\begin{array}{l}-.042 \\
(.076)\end{array}$ & Per se law & $\begin{array}{l}-.014 \\
(.103)\end{array}$ & Per se law & $\begin{array}{c}-.094 * * \\
(.046)\end{array}$ \\
\hline $\mathrm{N}$ & 189 & $\mathrm{~N}$ & 147 & $\mathrm{~N}$ & 273 \\
\hline Minnesota & & Nevada & & North Carolina & \\
\hline Per se law & $\begin{array}{l}.045 \\
(.061)\end{array}$ & Per se law & $\begin{array}{l}.091 \\
(.089)\end{array}$ & Per se law & $\begin{array}{l}.085 * * \\
(.035)\end{array}$ \\
\hline $\mathrm{N}$ & 126 & $\mathrm{~N}$ & 105 & $\mathrm{~N}$ & 231 \\
\hline Ohio & & Pennsylvania & & Rhode Island & \\
\hline Per se law & $\begin{array}{l}.080^{*} \\
(.042)\end{array}$ & Per se law & $\begin{array}{l}.013 \\
(.058)\end{array}$ & Per se law & $\begin{array}{l}-.291 \\
(.177)\end{array}$ \\
\hline $\mathrm{N}$ & 210 & $\mathrm{~N}$ & 126 & $\mathrm{~N}$ & 63 \\
\hline Utah & & Virginia & & Wisconsin & \\
\hline Per se law & $\begin{array}{l}.164 * * \\
(.065)\end{array}$ & Per se law & $\begin{array}{l}.090 * * \\
(.041)\end{array}$ & Per se law & $\begin{array}{l}.057 \\
(.058)\end{array}$ \\
\hline $\mathrm{N}$ & 168 & $\mathrm{~N}$ & 189 & $\mathrm{~N}$ & 231 \\
\hline Year FEs & Yes & & Yes & & Yes \\
\hline State FEs & Yes & & Yes & & Yes \\
\hline State covariates & Yes & & Yes & & Yes \\
\hline State-specific trends & Yes & & Yes & & Yes \\
\hline
\end{tabular}

*, statistically significant at $10 \%$ level; **, at $5 \%$ level; ***, at $1 \%$ level.

Notes: Each cell represents the results from a separate regression where the state in bold font indicates the treated state. The dependent variable is equal to the natural $\log$ of total traffic fatalities per 100,000 population and the covariates are listed in Appendix Table 2. Control states are selected by the procedure developed by Abadie et al. (2010) and regressions are weighted using the synthetic control weights. Robust standard errors are in parentheses. 
Figure 1. Traffic Fatality Trends in States with and without a Per Se Drugged Driving Law, 1990-2010
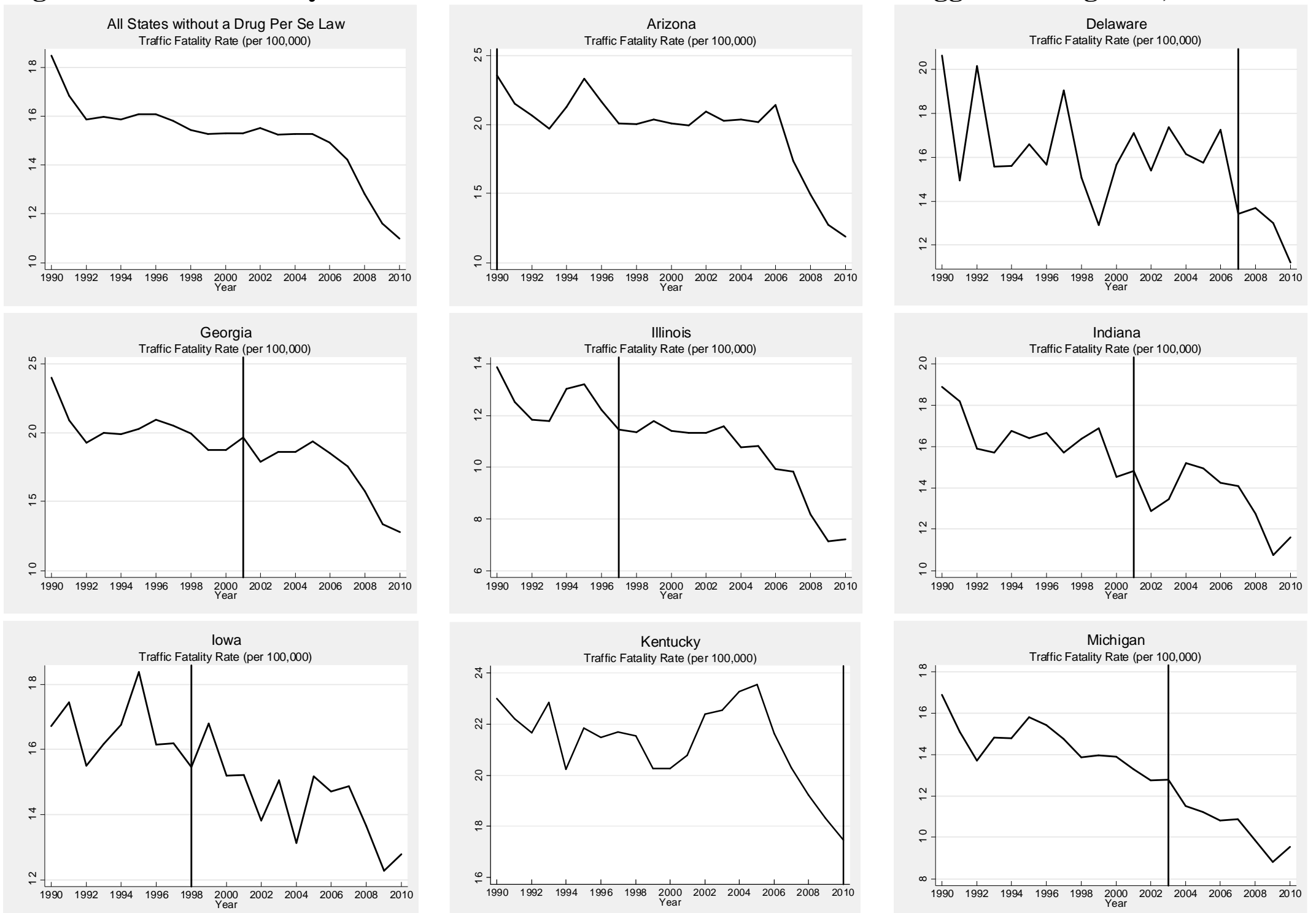

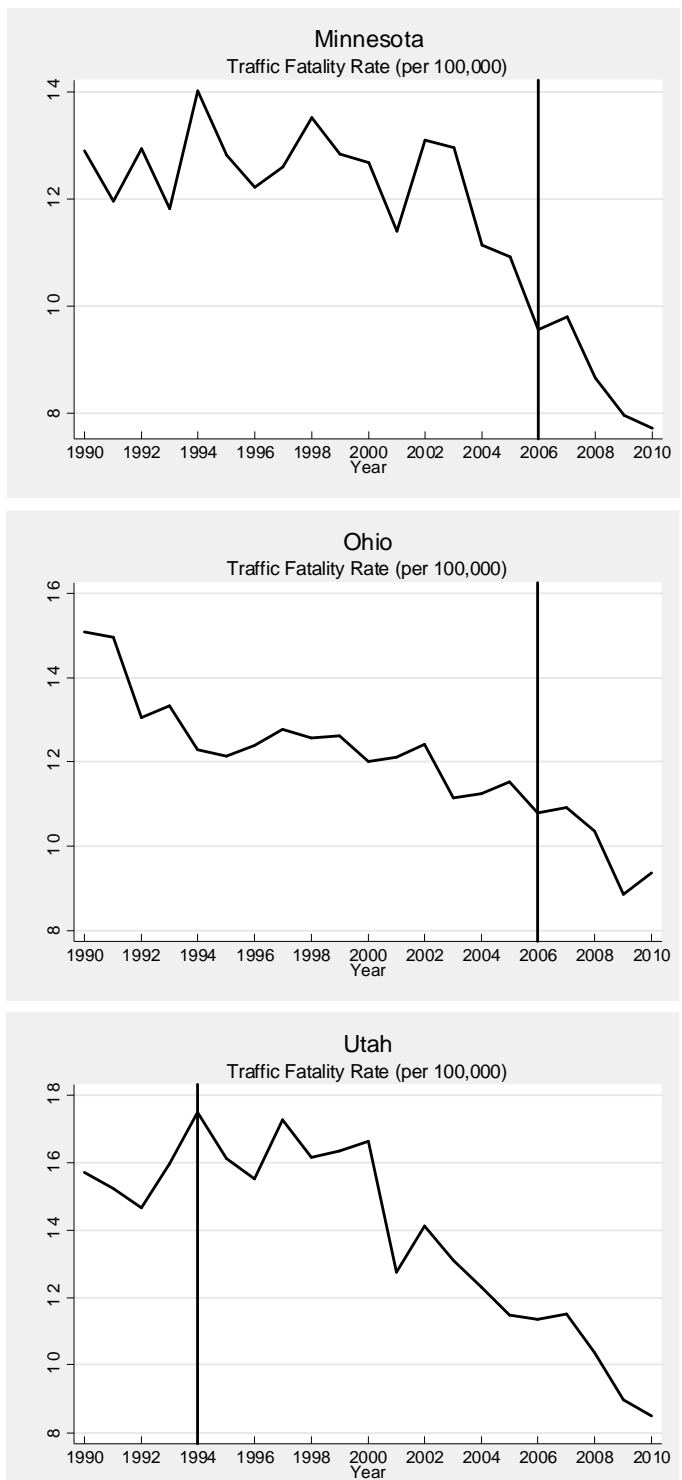
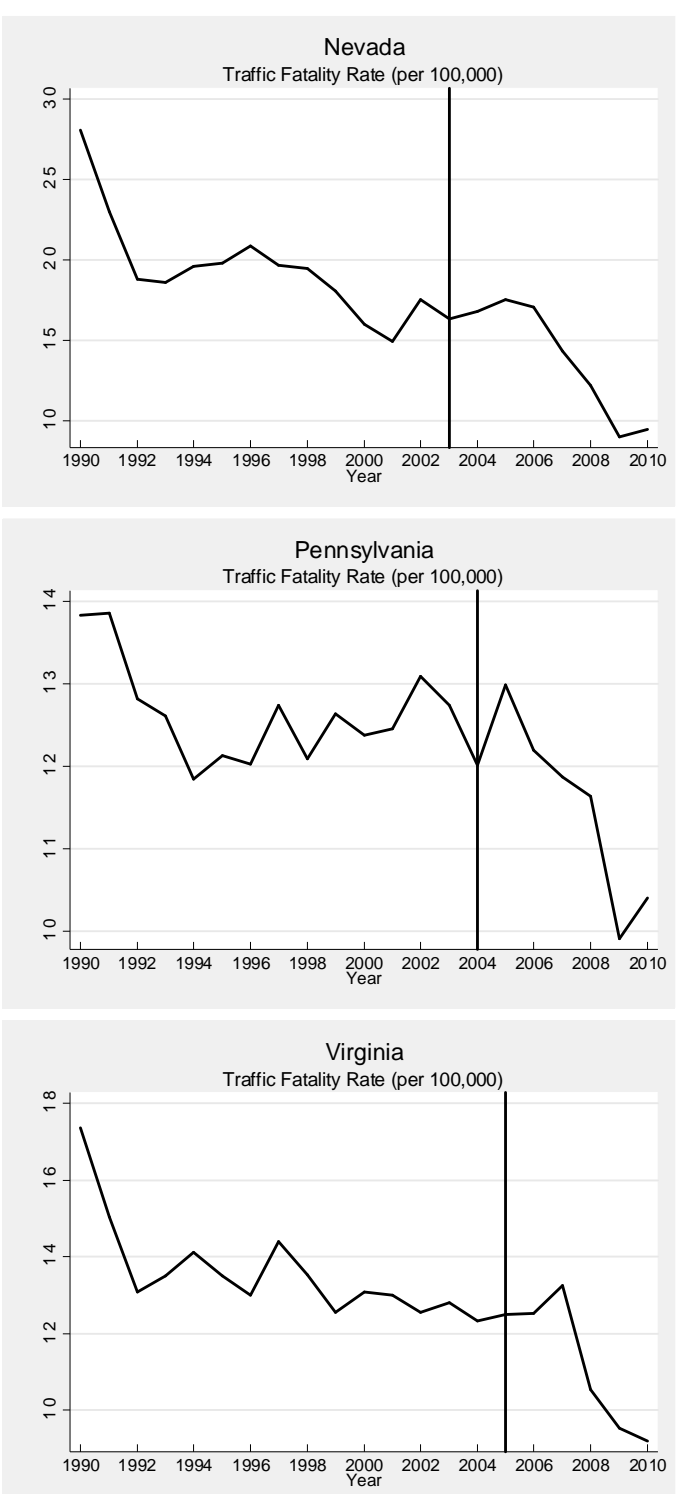
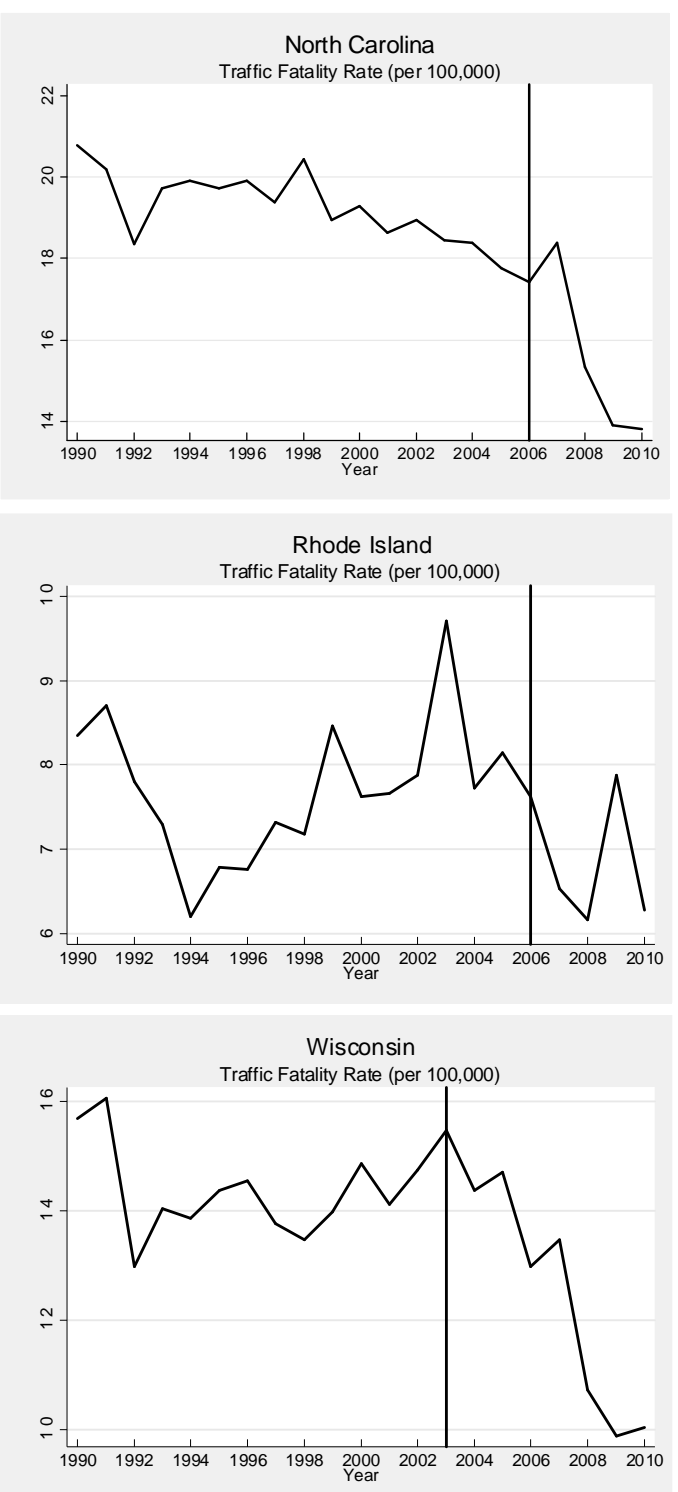

Note: Vertical lines represent the year in which a per se drugged driving law came into effect. 
Figure 2. Traffic Fatality Trends in States with a Per Se Law vs. Synthetic Control States, 1990-2010
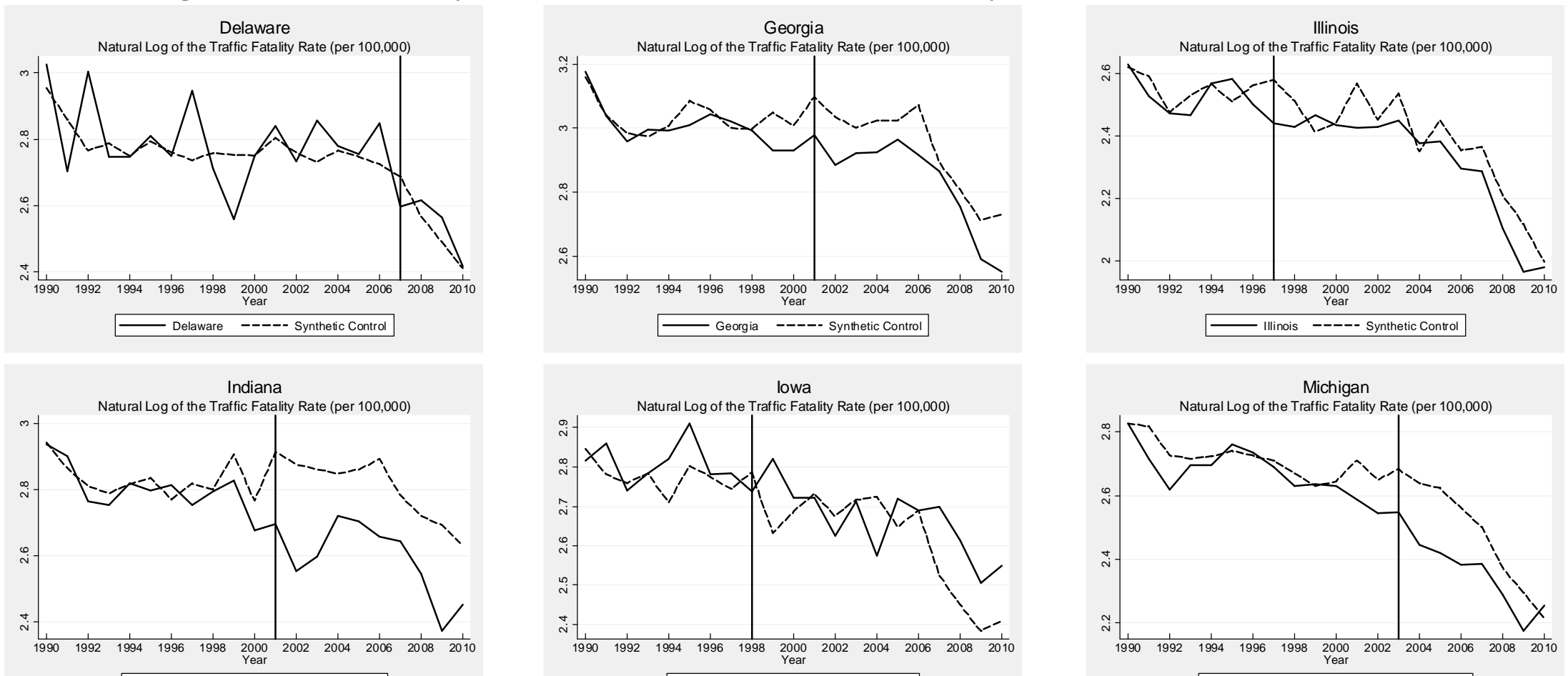

— Indiana ----- Synthetic Control
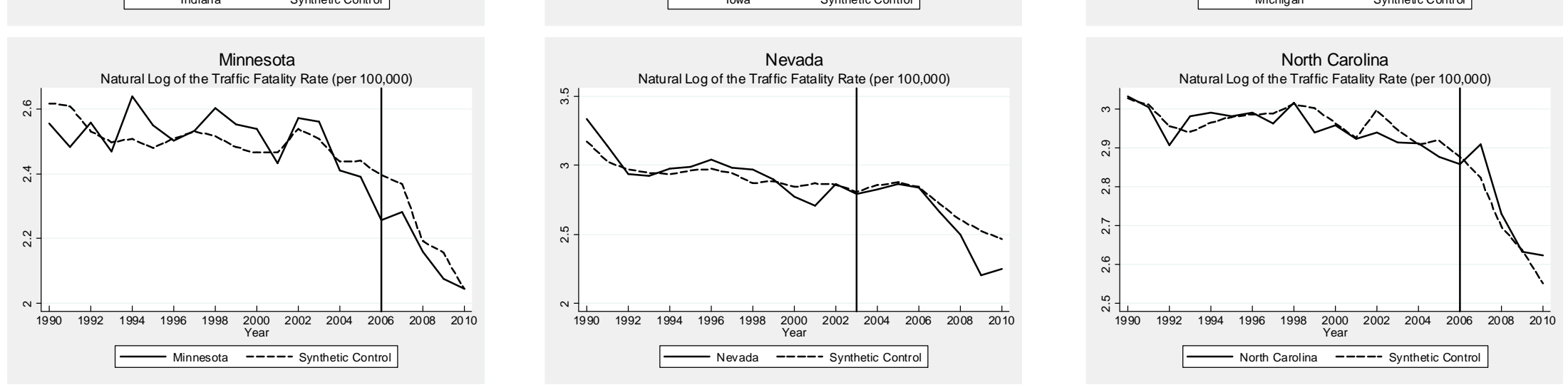

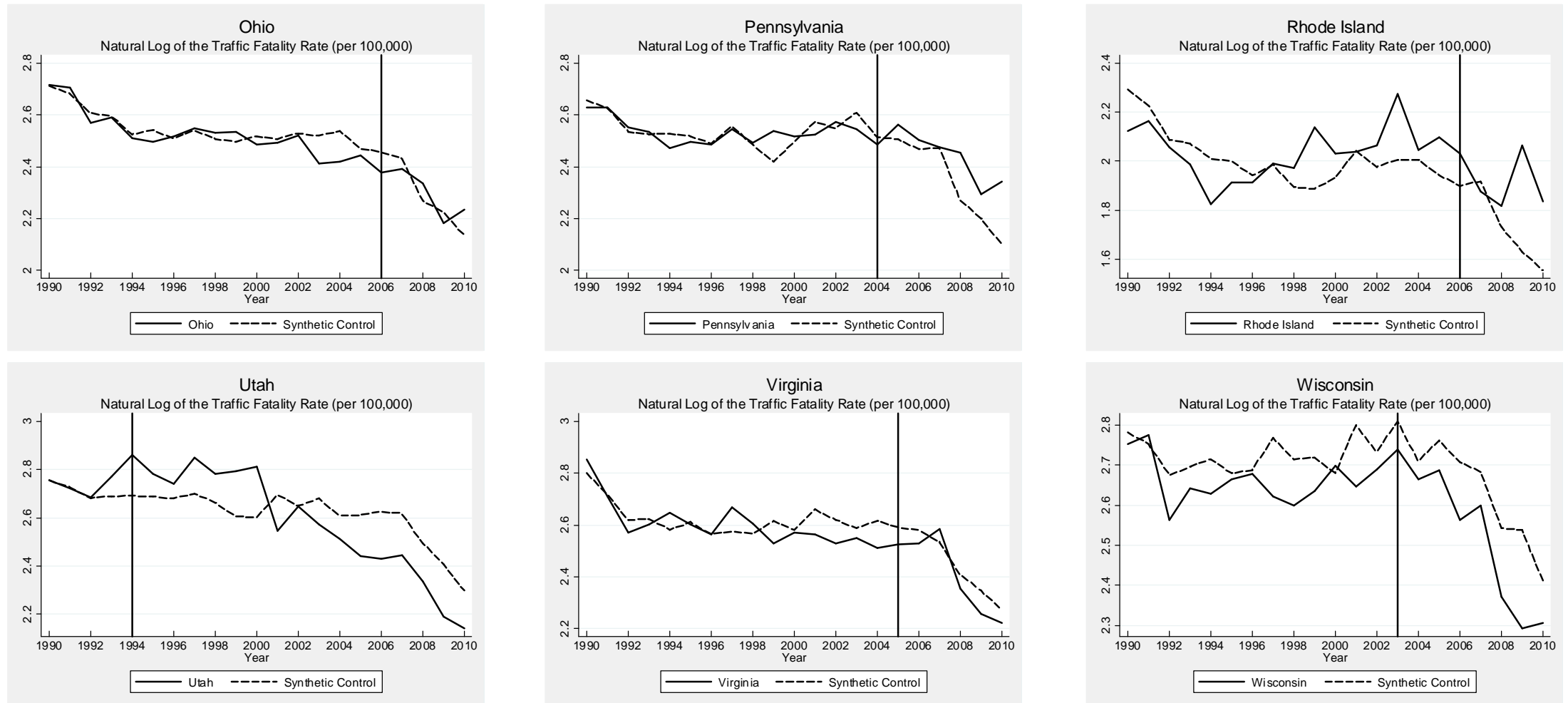

Note: Vertical lines represent the year in which a per se drugged driving law came into effect. 


\section{Appendix Table 1. Descriptive Statistics for FARS Analysis (Dependent Variables)}

\begin{tabular}{lcl} 
Variable & Mean (SD) & \multicolumn{1}{c}{ Description } \\
\hline Traffic Fatalities & $14.58(5.05)$ & $\begin{array}{l}\text { Number of fatalities per 100,000 } \\
\text { population }\end{array}$ \\
Variable & Mean (SD) & \multicolumn{1}{c}{ Denominator } \\
\hline Fatalities Weekdays & $8.32(2.88)$ & per 100,000 population \\
Fatalities Weekend & $6.22(2.25)$ & per 100,000 population \\
Fatalities Daytime & $7.04(2.59)$ & per 100,000 population \\
Fatalities Nighttime & $7.42(2.60)$ & per 100,000 population \\
Fatalities 15-19 year-olds & $24.55(9.75)$ & per 100,000 15- through 19-year-olds \\
Fatalities 20-29 year-olds & $23.59(8.41)$ & per 100,000 20- through 29-year-olds \\
Fatalities 30-39 year-olds & $15.45(6.49)$ & per 100,000 30- through 39-year-olds \\
Fatalities 40-49 year-olds & $14.00(5.63)$ & per 100,000 40- through 49-year-olds \\
Fatalities 50-59 year-olds & $13.22(4.93)$ & per 100,000 50- through 59-year-olds \\
Fatalities 60+ year-olds & $17.39(5.28)$ & per 100,000 60-year-olds and above \\
Fatalities Males & $20.48(7.15)$ & per 100,000 males \\
Note: Weighted means based on the FARS state-level panel for 1990-2010. & per 100,000 females \\
\hline
\end{tabular}




\section{Appendix Table 2. Descriptive Statistics for FARS Analysis (Independent Variables)}

\begin{tabular}{|c|c|c|}
\hline Variable & Mean (SD) & Description \\
\hline Per se law ${ }^{a}$ & $0.149(0.351)$ & $\begin{array}{l}=1 \text { if a state had a drug per se law in a } \\
\text { given year, }=0 \text { otherwise }\end{array}$ \\
\hline Mean age & $44.15(1.40)$ & $\begin{array}{l}\text { Mean age of the state driver population } \\
\text { (16 years of age and older) }\end{array}$ \\
\hline Unemployment & $5.87(1.87)$ & State unemployment rate \\
\hline Income & $10.27(0.156)$ & $\begin{array}{l}\text { Natural logarithm of state real income } \\
\text { per capita ( } 2000 \text { dollars) }\end{array}$ \\
\hline Miles driven & $14.13(2.05)$ & $\begin{array}{l}\text { Vehicle miles driven per licensed driver } \\
\text { (thousands of miles) }\end{array}$ \\
\hline Medical marijuana ${ }^{a}$ & $0.130(0.334)$ & $\begin{array}{l}=1 \text { if a state had a medical marijuana } \\
\text { law in a given year, }=0 \text { otherwise }\end{array}$ \\
\hline Decriminalized $^{a}$ & $0.330(0.470)$ & $\begin{array}{l}=1 \text { if a state had a marijuana } \\
\text { decriminalization law in a given year, = } \\
0 \text { otherwise }\end{array}$ \\
\hline$B A C 0.08^{a}$ & $0.584(0.485)$ & $\begin{array}{l}=1 \text { if a state had a } 0.08 \text { BAC law in a } \\
\text { given year, }=0 \text { otherwise }\end{array}$ \\
\hline Zero Tolerance ${ }^{a}$ & $0.763(0.417)$ & $\begin{array}{l}=1 \text { if a state had a "Zero Tolerance" } \\
\text { drunk driving law in a given year, }=0 \\
\text { otherwise }\end{array}$ \\
\hline Beer tax & $0.245(0.207)$ & Real beer tax (2000 dollars) \\
\hline Graduated driver licensing $^{a}$ & $0.522(0.493)$ & $\begin{array}{l}=1 \text { if a state had a graduated driver } \\
\text { licensing law with an intermediate phase } \\
\text { in a given year, }=0 \text { otherwise }\end{array}$ \\
\hline Primary seatbelt ${ }^{a}$ & $0.461(0.494)$ & $\begin{array}{l}=1 \text { if a state had a primary seatbelt law } \\
\text { in a given year, }=0 \text { otherwise }\end{array}$ \\
\hline Secondary seatbelt ${ }^{a}$ & $0.518(0.494)$ & $\begin{array}{l}=1 \text { if a state had a secondary seatbelt } \\
\text { law in a given year, }=0 \text { otherwise }\end{array}$ \\
\hline $\begin{array}{l}\text { Administrative license } \\
\text { revocation }^{a}\end{array}$ & $0.721(0.445)$ & $\begin{array}{l}=1 \text { if a state had an administrative } \\
\text { license revocation law in a given year, = } \\
0 \text { otherwise }\end{array}$ \\
\hline Speed 70 & $0.463(0.499)$ & $\begin{array}{l}=1 \text { if a state had a speed limit of } 70 \mathrm{mph} \\
\text { or greater in a given year, }=0 \text { otherwise }\end{array}$ \\
\hline Texting ban ${ }^{a}$ & $0.041(0.185)$ & $\begin{array}{l}=1 \text { if a state had a cell phone texting } \\
\text { ban in a given year, }=0 \text { otherwise }\end{array}$ \\
\hline Hands Free ${ }^{a}$ & $0.025(0.150)$ & $\begin{array}{l}=1 \text { if a state had a "Hands Free" cell } \\
\text { phone law in a given year, }=0 \text { otherwise }\end{array}$ \\
\hline
\end{tabular}

